\title{
Reflexões sobre o conceito de direito e seu encontro com a literatura a partir da desconstrução
}

\section{Reflections on the concept of law and its encounter with literature from the perspective of deconstruction}

\author{
Fernando José Armando Ribeiro ${ }^{1}$, Bernardo Gomes Barbosa Nogueira²
}

\begin{abstract}
RESUMO
O presente texto dialoga com a obra "A besta e o soberano" de Jacques Derrida em um encontro com o pensamento de Slavoj Zizeck a respeito da violência, além de tratar alguns conceitos de Roland Barthes com o intuito de evidenciar a noção violenta que constitui o próprio do direito, apontando como a literatura, na perspectiva do movimento "Direito e Literatura", pode contribuir para avivar a discussão acerca da necessidade de desconstrução do conceito de direito instituído na história ocidental.
\end{abstract}

Palavras chave: Desconstrução; Soberano; Derrida Violência; Direito.

\section{ABSTRACT}

The present text dialogues with Jacques Derrida's work "The Beast and the Sovereign" as well as with Slavoj Zizeck's thoughts about violence. It aims to explore the violent dimension of law, pointing out how literature, from the perspective of the "Law and Literature" movement, can help to stimulate the deconstructionist discussions of the concept of law as established in Western tradition.

Key words: Deconstruction; sovereign; Derrida; Violence; Law.

1 Doutor em Direito pela UFMG, Belo Horizonte, MG, Brasil; Pesquisador da Universidade da Califórnia, Berkeley, Califórnia, EUA; Professor dos cursos de Mestrado e Bacharelado da PUC-Minas, Belo Horizonte, MG, Brasil; Desembargador do Tribunal de Justiça Militar do Estado de Minas Gerais, Belo Horizonte, Brasil. E-mail: fernandoarmandoribeiro@gmail.com

${ }^{2}$ Doutor em Direito pela PUC/MG. Professor do curso de Direito e do Mestrado em Gestão Integrada do Território da Universidade do Vale do Rio Doce - UNIVALE. Mediador credenciado pelo TJ/MG. 


\section{INTRODUÇÃO: A PASSO DE LOBO ${ }^{3}$}

\section{Diante dos seminários intitulados $A$ besta e o soberano de Jacques Derrida,} iremos aqui propor uma leitura para sustentar a necessidade de uma desconstrução do direito. Diante da besta. Diante do soberano. Diante da besta que é soberana? Tendo em conta que a questão do próprio, do próprio do direito, da ordem soberana, sempre se mostra enquanto violência, a questão aqui é imperativa, e isso por duas questões: primeiro pelo fato de tornar clara a possibilidade de a partir de uma fábula ${ }^{4}$ explicarmos como a questão do soberano, da ordem, do direito, está muito mais aproximada daquilo que ele quer condenar: a besta é soberana. Além disso, pensar dentro de nossa hipótese da relação direito e literatura, não apenas as dimensões positivas que a fábula traz, por assim dizer pedagógicas ${ }^{5}$, como também que aquilo que é da ordem do direito, que vem

\footnotetext{
${ }^{3}$ Fábula de La Fontaine, O lobo e o Cordeiro. O segundo bebia água do córrego quando é surpreendido por um lobo, um pouco acima do curso do regato. Esse o questiona pelo absurdo de sujar sua água. $\mathrm{O}$ Cordeiro lhe responde que tal seria impossível, pois ele estava abaixo da correnteza. Sem se dar por satisfeito, o lobo insiste na alegação de ofensa afirmando que o Cordeiro o caluniaria ano passado. E recebe como resposta o argumento de que a ofensa era impossível, pois o Cordeiro tinha apenas seis meses de idade. Não se dando por satisfeito, o Lobo disse que a calúnia partiu do irmão do cordeiro. Ao que recebe a informação de que ele era filho único. Já alterado, a fera disse que a ofensa partira ou do seu pai ou avô, melhor, que não importava mais a argumentação e o devorou [...] Mais do que uma nova releitura, uma desconstrução de uma fábula de crianças capaz de mostrar que Jusnaturalistas e Positivistas não percebem que o Direito foi, é e será fundado por um ato de violência. Derrida atesta que a instituição do Direito se dá sempre por um ato de força física e/ou política que estabelecerá um plano normativo sempre favorável aos Senhores do Poder, o Soberano. Para ele, a soberania não se marca pela capacidade de moldar a regra, mas fundamentalmente a de superá-la sempre que fora da conveniência do Soberano. Maioria de votos ou bons argumentos jamais impedem o Soberano de se impor com, no e pelo Direito, assim como não impedem o Lobo de devorar o Cordeiro. (CRUZ, 2017, p. X)

${ }^{4}$ Mas em princípio, e seguindo a sua vocação estatutária, seguindo a lei e o contrato que ela supõe, o discurso docente não deve ser fabuloso. Ele dá a saber, ele difunde o saber, mas é preciso saber sem fábula. E é preciso fazer saber sem fábula. Ao mesmo tempo, na tradição prevalecente e hegemônica do político, um discurso político, e, sobretudo, uma ação política, não devia em caso algum porvir do fabuloso, desse tipo de simulacro que se chama fabuloso, desse tipo de linguagem que se denomina fábula, seja fábula em geral, seja fábula como gênero literário determinado no Ocidente europeu. Pois, como seu nome latino indica, uma fábula é sempre e antes de tudo uma palavra - for, fari significa falar, dizer, celebrar, cantar, predizer, e fabula é de início uma frase, uma fala familiar, uma conversação, depois uma narrativa mítica, sem saber histórico, uma lenda, por vezes uma peça de teatro, em todo caso uma ficção que pretende nos ensinar alguma coisa, uma ficção supostamente dá a saber, uma ficção supostamente faz saber [...] O fabuloso da fábula não diz respeito apenas à sua natureza linguística, ao fato de que a fábula é constituída por palavras. O fabuloso engaja também o ato, o gesto, a ação, não menos do que a operação que consiste em produzir um relato, em organizar, dispor o discurso de modo a contar, a colocar em cena os viventes, a tornar crível a interpretação de um relato, a "fazer saber", a fazer o saber, a fazer performativamente, a operar o saber (um pouco como Agostinho falava de fazer a verdade veritatem faciare). (DERRIDA, 2016, p. 63-65)

${ }^{5}$ Não tenho dúvida de que a literatura pode ensinar muito ao direito. Faltam grandes narrativas no direito. A literatura pode humanizar o direito. Há vários modos de dizer as coisas [...] A cotidianidade do direito não nos toca. Ou seja, a realidade não nos "diz nada". Mas, as ficções, sim. Com isso, confundimos as ficções da realidade com a realidade das ficções. Ficamos endurecidos. A literatura pode ser mais do que isso. Necessitamos do absurdo, do impossível, para constatarmos a crueldade do
} 
dita por ele, assim como aquilo que deve se manter à margem, a priori, também é violentamente por ele determinado. Se alcançarmos nosso intento, daqui já poderemos vislumbrar nossa ideia de que cada ato de encontro do direito com a literatura deveria ser tomando como fonte de invenção e de hospitalidade para aquele, aquilo que vem, e que por vezes não chega, pois fora devorado pelo lobo.

\section{NA SELVA}

Mais um passo e nos deparamos, dentro do direito, da ordem soberana e democrática do direito, com um lobo. Sempre o lobo está ali, enquanto soberano, democracia e direito, sempre e diante de qualquer coisa que se arrogue a esse nome, a essa nomenclatura, a essa dimensão de soberania.

Nesta pegada, podemos adiantar que as discussões aqui afetam a dimensão da ordem jurídica, seja ela democrática ou não, o lobo é figura esguia, noturna, tem um corpo mutante, é um animal que se confunde com seu habitat, que confunde mesmo o habitat. Essa fala é importante pois o problema da ordem jurídica não se deslinda a partir das transformações que ela se propõe, ou seja, a camuflagem do lobo, sua maneira de esconder-se confunde, por isso, tem-se a impressão de não haver lobo, por isso, é sempre importante afirmarmos, o lobo sempre está "a passo de lobo", portanto, "nada de lobo".

Uma figura que amedronta, que nos faria porventura socorrer à ordem, ao próprio direito para nos defender dele. Nós nos socorrermos do lobo. Onde nos esconderíamos do lobo? Quem é esse lobo que nos espreita? Perguntar quem é esse lobo não seria já uma maneira de querer captá-lo à nossa medida? À nossa maneira soberana? O lobo sempre caminha, a passo de lobo, um jeito sinuoso de se envolver por entre a mata noturna e sempre assombrar. Talvez a surpresa seja sempre isso que estaria por detrás e no próprio do lobo. Que besta é essa que esgueira por entre a floresta e não se deixa ver?

Há já na primeira frase do parágrafo acima um problema. Como falar que encontramos com o lobo dentro da ordem violenta do direito e ao mesmo tempo nos socorrermos a ela para nos defendermos dele? "A passo de lobo". Haveria aí um erro de

mundo que nos cerca, por isso precisamos da literatura, mostrando novas formas, de um novo lugar de fala, nas palavras de Barthes (ou situação hermenêutica, para falamos com Gadamer), para demonstrarmos o que é digno de crítica. Ela pode ser o canal de aprendizado do direito nas salas de aula. (STRECK, 2013, p. 60-62) 
cálculo de quem foge do lobo? Ou, ao contrário, as coisas não se deem assim de forma tão clara que deveríamos observar mesmo qual a relação do lobo com a ordem? "Da besta com o soberano"? ${ }^{6}$ É nessa via de reflexões que nos colocaremos. A questão que se impõe agora é procurar mostrar como a ordem, o direito, estão aproximadas desse lobo, e que Jacques Derrida chama de besta anunciado em seu seminário A besta e o soberano; por evidente não se trata de uma análise completa dos seminários reunidos sob essa alcunha, o que interessa nesse momento é procurar aproximarmos mais ainda nossa leitura daquilo que está por detrás, ao lado, e sobretudo ao fundo da ordem e que porventura ela não queira deixar mostrar, esguia vem "a passo de lobo".

O lobo não se mostra. É muito complicada uma relação com um lobo, ele, parece, quase sempre, se coloca em uma situação privilegiada, anda "a passo de lobo", é ágil, esgueira, confunde-nos com o local mesmo de sua habitação, com a ordem que habita, com a ordem que comanda, que o circunda e que, ao fim, mostra-se ele mesmo soberano, o soberano.

O lobo normalmente tem hábitos noturnos. As pessoas que estão "fora da lei" também têm hábitos noturnos. Quais são os horários da ordem? Ela se distingue do lobo pelos horários? Ela se distingue do lobo? Aqueles que são postos fora da lei necessitam não estar entregues aos holofotes. A ordem quer a todo momento capturá-los, é dizer, devorá-los, eles se esgueiram, pervertem a ordem do tempo, maquinam durante o dia, o lobo descansa sobre a relva durante o dia. Em um santuário localizado na Serra do Caraça em Minas Geras está-se sempre à espreita do Lobo-Guará. Nesse parque, há também a hora do lobo, a hora que o lobo vem. Ele não aparece em hora marcada, apesar de haver "a hora do lobo", criada pelos padres que ali vivem, que querem

\footnotetext{
${ }^{6}$ A besta $e$ o soberano, a besta é o soberano, assim se anunciaria de início o casal, um casal, um duo, até mesmo um duelo, mas também uma aliança [...] olho no olho ou face a face, assombrados pelas diferenças sexuais virtuais entre, por um lado, a simples conjunção (e) que os posicionaria, oporia ou justaporia como duas espécies viventes radicalmente heterogêneas uma à outra, uma infra-humana, a outra humana, e mesmo sobre-humana, e, por outro lado, a cópula (é) que os acoplaria em uma espécie de atração ontológico-sexual, de fascinação mútua, de ligação comunitária, até mesmo de semelhança narcísica, um reconhecendo no outro uma espécie de duplo, um se tornando o outro, sendo o outro (o "é" tendo, então, valor de processo, de devir, de metamorfose identificatória), a besta sendo o soberano, o soberano sendo a besta, um e outro se encontrando um e outro engajados, em verdade, mudados, e mesmo cambiados em um devir-besta do soberano ou em um devir-soberano da besta, a passagem de uma para o outro, a analogia, a semelhança, a aliança, o hímen que se deve ao fato de que eles compartilham todos os dois dessa posição muito singular de serem fora-da-lei, acima ou à parte do direito, a besta ignorando o direito e o soberano tendo o direito de suspender o direito, de se colocar acima da lei que ele é, que ele faz, que ele institui, sobre a qual ele decide de maneira soberana. O soberano não é um anjo, mas, dir-se-ia, aquilo que faz o soberano faz a besta. O soberano se faz besta, se faz a besta, por vezes no sentido mais turvo de uma zoofilia. (DERRIDA, 2016, p. 61-62)
} 
domesticar o lobo, talvez docilizar o lobo, serem soberanos do lobo, contudo, não podemos supor necessariamente se ele virá, se ele é um dos padres que alimentam o lobo, que se alimentam enquanto lobos. De onde ele virá? Quem é a besta? Quem é o soberano?

O lobo quase sempre aparece à noite. E sempre é interessante perceber as palavras, as expressões: "na calada da noite", na "noite silenciosa", mas apenas por uma suposição, uma invenção ou apropriação que está na ordem do humano. A noite não é nada silenciosa para os lobos, tampouco, a noite é silenciosa para aqueles que, como lobos, estão postos fora da lei. Eles agem na "calada da noite", conferem som à noite. Já aí uma dicção importante, ou seja, durante o dia haveria os humanos que estão na lei, que se apoderam dela, os soberanos/lobos da lei; pela noite, sorrateiros, criminosos, agem os fora da lei, aqueles lobos que estamos aqui a nos referir - e logo sacamos o problema que nós mesmos incorremos ao dizer do lobo. Nós queremos ser soberanos deles, inclusive dizer que eles são lobos, nós, civilizados e ordeiros, de dentro da ordem. Mas, se a besta é soberana, só podemos dizer de dentro do lobo - de dentro do lobo dizemos quem é o lobo, uivamos! E isso remete a Renan Inquérito com seu rap: "nós 'tamo' dentro dos monstros, e eles dentro da gente"'. Aqueles que ao menor sinal afugenta-se, aqueles sob os quais se quer manter soberania, a besta é soberana, enfim. Novamente o perigo da soberania, a proximidade entre a besta e o soberano, sua hipótese de confusão, essa oscilação é o que iremos perscrutar. ${ }^{8}$

O lobo assombra a ordem e a ordem assombra o lobo. Ele não respeita a ordem. Procura uma brecha. Ela não respeita o lobo. Cria a brecha. Atuam no não lugar, sempre a passo/nada de lobo, e é importante perceber que o léxico da palavra "pas", no francês, também significa “nada, não", pas, então, nada de lobo, a passo/nada de lobo" .

\footnotetext{
${ }^{7}$ Não é com os olhos que se enfrenta o mito (Los Reyes). A única saída do labirinto é ir ao encontro de si mesmo. A única forma de liquidar uma esfinge é atribuir-lhe outro enigma aceitando o primeiro como tal. O único meio para matar os monstros é aceitá-los (Los Reyes). (WARAT, 1985, p. 46)

${ }^{8}$ Dentro de uma dimensão de "ecologia dos saberes" trazemos o trecho de um rap que esteve presente em uma das aulas magistrais de Boaventura de Sousa Santos e que fora escrito e declamado pelo raper Renan Inquérito: "Nós 'tamo' dentro dos monstros e eles, dentro da gente, somos problema e solução simultaneamente, o monstro parece grande, de perto é ainda maior, mas quando a gente se afasta, vai ficando menor, menor, menor, menor, menor, menor, menor, menor, menor, menor, menor, menor, menor, menor, menor, enorme [...]". (SANTOS, 2017).

${ }^{9}$ Uma das numerosas razões pelas quais escolhi, nesse amontoado de provérbios, esse que forma o sintagma "a passo de lobo", está precisamente o fato de que a ausência do lobo se diz aí também na outra operação silenciosa do "passo", do vocábulo "passo" em francês (pas) que deixa ouvir, ainda que sem nenhum alarde, a intrusão selvagem da negação "pas" (passo/negação, passo de lobo / nada de lobo, não há lobo algum, não há lobo), a intrusão clandestina, então, do advérbio de negação "pas" no nome, no "o passo do lobo". Um advérbio assombra um nome. O advérbio "pas" (não) se introduz em
} 
Estamos condenados a esse perigo sempre que estamos próximos aos lobos. Sempre estaremos próximo dos lobos, estamos na ordem do direito, do soberano. A passo de lobo esgueiram pelas ruas aqueles que estão fora da lei. Eles estão condenados à rua? Os lobos não vivem nas cidades. Os lobos não vivem nas cidades? Mais uma vez é importante prestarmos atenção às expressões, por exemplo, "selva de pedra", que é como as grandes metrópoles são chamadas.

Jacques Derrida empresta em sua imensa reflexão a partir de uma fábula de La Fontaine (1997) que se chama $O$ lobo e o cordeiro e que informa: "A razão do mais forte é sempre a melhor". Não adiantemos as coisas. Ainda na pegada do que nos propusemos, para além daquilo que já foi levantado à guisa de provocação reflexiva, convocaremos alguns conceitos extraídos de Slavoj Zizek (2014) para sustentarmos nossa reflexão iniciada com a noção de que a violência é congênita ao direito, congênita à ordem - tenha ele o nome que quisermos dar -, congênita ao soberano, ao lobo, ao criminoso. Vamos a essas discussões.

\section{VIOLÊNCIAS SELVAGENS}

Estes dois conceitos que iremos explorar são extraídos junto de Slavoj Zizek (2014) a partir do livro intitulado Violência e que já na introdução "O manto sagrado 10 do tirano" traz algumas linhas que iremos percorrer, mas que não esgotam, por certo, o intento do autor. A questão que gostaríamos de deslindar nesta parte de nossa reflexão está intimamente ligada em relação à ideia de que a violência opera em uma dimensão congênita ao direito, ou se pudermos levar a expressão para outro local, que é uma dimensão que envolve, que dá a luz ao próprio direito, à própria ordem; dimensão que envolve, também poderíamos dizer que é a luz do próprio/do direito.

É preciso lembrar que, onde há excesso de luz, não se pode ver. O lobo se vale da noite para não se mostrar, anda sempre "a passo/nada de lobo"; há aqui um importante momento, o excesso de luz, de justificativas, de leis, de alguma maneira,

silêncio, a passos de lobo, no nome "pas" (passo). (DERRIDA, 2016, p. 22)

${ }^{10} \mathrm{E}$, sobretudo, mais interessante para nós nesse ponto, a dupla exclusão da qual falamos, lá onde ela associa na não-convenção a besta e Deus, assim como a não resposta, nos dá a pensar que o soberano do soberano, Deus, Ele, Ele também não, como a besta, Ele não responde, que, em todo caso, nós não podemos contar com Sua resposta. E essa é a definição mais profunda da soberania, dessa absolutidade que absolve, que a desliga de todo dever de reciprocidade. O soberano não responde, ele é aquele que pode, que tem sempre o direito de não responder, em particular, de não responder pelos seus atos. Ele está acima do direito que ele tem o direito de suspender [...] O soberano tem o direito de não responder, ele tem o direito ao silencio dessa dissimetria. Ele tem o direito a certa irresponsabilidade. (DERRIDA, 2016, p. 94-95) 
deixam sem o poder de ver, cegos diante da lei, um jeito de escamotear o que ela é em seu fundamento, suas fantasias e adereços. Junto disso, tateamos, andamos, "a passo de lobo", antes de tratar destas distinções da violência, também como forma de aliar os termos e de outra vez e quantas forem necessárias, mostrar a violência que envolve a ordem, mas que ela, esguia que é, feito o lobo, esconde, escamoteia.

Em jeito de firmar bem nossa posição, talvez seja importante dizer explicitamente que não percorreremos qualquer caminho que queira apontar um local de chegada. Nossa escrita está e estará sempre na toada da travessia, da necessidade de atravessamento pela dimensão da ordem, o que significa dizer que não supõe-se que haverá a hipótese de fundação, de refundação, se quisermos, de um direito, de uma ordem jurídica, de uma ordem jurídica constitucional e democrática, sem que esteja já em sua gestação, em seu gene, a dimensão da violência, isso fica claro a nós na aproximação e confusão do lobo com o soberano, do lobo com a ordem, mais uma vez, seja ela adjetivada como for.

Essa proximidade com a fábula é importante exatamente porque o lobo é uma figura que em seu habitat cria uma dificuldade de enxergá-lo, assim como a roupagem da ordem também acaba por esconder essa face. Jacques Derrida escancara que há algo de podre no próprio coração da ordem. Sabe-se de antemão que a desconstrução não significa a destruição da ordem, pois, assim como no discurso metafísico que supõe a ordem, todos estão dentro dele/dela, temos as "armas" dele/dela, a linguagem dele/dela, e assim, e por essa possiblidade de percebermos que as coisas podem não se manter desse jeito é que continuaremos a atravessar. Guimarães Rosa (1994b) mostra em seu Grande Sertão que ao nos lançarmos para a travessia, o local que aportamos é bem outro daquele que pensávamos à partida; estamos sempre na hipótese da travessia, da desconstrução enquanto travessia:

\footnotetext{
Ah, tem uma repetição, que sempre outras vezes em minha vida acontece. Eu atravesso as coisas - e no meio da travessia não vejo! só estava era entretido na ideia dos lugares de saída e de chegada. Assaz o senhor sabe: a gente quer passar um rio a nado, e passa; mas vai dar na outra banda é num ponto muito mais embaixo, bem diverso do em que primeiro se pensou. Viver não é muito perigoso? (ROSA, 1994b, p. 42)
}

O lobo estará certamente na outra margem, ele quer sempre dizer quando e como podemos atravessar, por isso importa atravessá-lo, ele irá sobreviver, aliás, “a 
razão do mais forte é a melhor", mas essa afirmação não significa que seja a única, menos ainda que seja a melhor. Daí que não vale a pena encarar a violência, a violência da ordem, querendo simplesmente domesticá-la, isso mostra à partida como o "humano" se assemelha ao lobo, o que Renan Inquérito deixou claro ao dizer que os monstros habitam em nós. Habitam exatamente pela sanha apropriadora que um pensamento fundado no próprio e na presença nos impinge.

A travessia supõe um outro que reclama, que está a ser devorado agora mesmo, por isso a necessidade da desconstrução, novamente, não como maneira ou modo, ou método de alcance de um fim, como se de um método se tratasse. Ou seja, a cada vez que o lobo se esquiva, que a ordem se esquiva, pois está-se sempre "a $o$ passo/nada de lobo", torna-se necessária, eticamente, juridicamente, filosoficamente, a desconstrução; não como saída para a violência, mas como um momento de torna-la distinta do que está sendo, pois o que ela é, a ordem, dá-nos enquanto violência.

Por isso, a nossa dicção não está a dizer da hipótese de implosão da ordem, mas sim de que sua raiz, sua semeadura, seu gene é violento, e ela não responderá de outra forma, entanto, ela é uma construção, e também por isso, deve, é preciso, que seja desconstruída ${ }^{11}$. De novo, não se trata de alcance de pontos de chegada: não haverá uma democracia $^{12}$ sem violência, nem um direito sem violência, nem uma ordem, qualquer que seja, sem violência. Mas ela se mostra "como se" não houvesse, por isso: "a passo/nada de lobo", e de outro lado, nós daqui vamos a avisar/desconstruir: há lobo ${ }^{13}$.

${ }^{11} \mathrm{O}$ que é chamado "desconstrução" [...] nunca se opôs a instituições como tais, à filosofia como tal, à disciplina como tal. No entanto, [...] fazer o que estou fazendo aqui é outra coisa pra mim. Porque, contudo, o caráter afirmativo da desconstrução, ela é afirmativa de uma maneira não simplesmente positiva, não simplesmente conservativa, não simplesmente de maneira a repetir a instituição já dada [...]. Se uma instituição é concebida para ser uma instituição, é preciso alguma ruptura com o passado, guardar a memória do passado enquanto se inaugura alguma coisa absolutamente nova. [...] É disso que a desconstrução é feita: não uma mistura, mas uma tensão entre memória, fidelidade, preservação de alguma coisa que nos foi dada, e, ao mesmo tempo, heterogeneidade, alguma coisa absolutamente nova, e uma ruptura. (CAPUTO, 1997 apud GRENHA, 2004, p. 74)

12 Ao dizer que a manutenção deste nome grego, a democracia, é uma questão de contexto, de retórica ou de estratégia, de polémica mesmo, ao reafirmar que este nome durará o tempo que for preciso, mas não mais, ao dizer que as coisas se aceleram singularmente nestes tempos que correm, não se cede necessariamente ao oportunismo ou ao cinismo anti-democrata que esconde seu jogo. Pelo contrário: salvaguarda-se o seu direito indefinido à questão, à crítica, à desconstrução (direitos garantidos, em princípio por toda a democracia: não há desconstrução sem democracia, não há democracia sem desconstrução). Salvaguarda-se este direito para marcar estrategicamente o que não é mais uma questão de estratégia: o limite entre o condicional (os bordos do contexto e do conceito que encerra a prática efectiva da democracia a alimentam no solo e no sangue) e o incondicional que, desde o começo, terá inscrito uma força auto-desconstrutiva no próprio motivo da democracia, a possiblidade e o dever de a democracia se de-limitar ela mesma. (DERRIDA, 2003, p. 117)

${ }^{13} \mathrm{Na}$ interpretação de Derrida, aquilo a que Benjamin chama força que faz lei, o acto de fundação de um novo sistema de direito, não pode de forma nenhuma ser executado dentro de fronteiras legais. " $A$ 
Slavoj Zizek, assim como Jacques Derrida em seus Seminários, inicia seu texto alertando para que devemos dar um passo. No caso deste último, "um passo para trás", ou seja, um passo/nada para trás. Não é possível recuar, ao mesmo tempo, não se pode estar afoito, está-se sempre "a passo/nada de lobo", na ordem, inserido nela, permitido por ela, por sua dimensão democrática. Slavoj Zizek solicita um passo atrás, um nada atrás em relação à tese sobre a violência.

Ele informa de que é necessário não estar friccionado, preso, alienado em relação à violência, que este aprisionamento do pensamento permitiria apenas que visássemos aquilo que se mostra, aquilo que está a vista, restando, assim como Jacques Derrida aponta, o mais importante a ser criticado. Ouçamos primeiro Slavoj Zizek (2014, p.17), para depois ouvirmos Jacques Derrida, eles estão ocupados com o lobo, pelo lobo, que sempre está "a passo/nada de lobo":

Se há uma tese unificadora nas reflexões que se seguem, é a de que existe um paradoxo semelhante no que diz respeito à violência. Os sinais mais evidentes de violência que nos vêm à mente são atos de crime e terror, confrontos civis, conflitos internacionais. Mas devemos aprender a dar um passo atrás, e desembaraçar-nos do engodo fascinante dessa violência "subjetiva" diretamente visível, exercida por um agente claramente identificável. Precisamos ser capazes de perceber os contornos dos cenários que engendram essas explosões. $\mathrm{O}$ passo para trás nos permite identificar uma violência que subjaz aos nossos próprios esforços que visam combater a violência (ZIZEK, 2014, p. 17).

E Jacques Derrida (2010):

O conceito de violência (Gewalt) só permite uma crítica avaliadora na

origem da autoridade, a fundação ou terreno, a posição da lei não pode, por definição, assentar sobre nada mais do que esses mesmos elementos". Esta declaração parece trivial se aplicada à posição de uma monarquia absoluta, por exemplo a de Luís XIV de França, que pronunciou a famosa afirmação "L'eta c'est moi". No entanto, na admirável perspectiva de Derrida, o caso de Thomas Jefferson e dos Pais da democracia parlamentar norte-americana não é diferente porque até mesmo aos princípios da Constituição norte-americana falta uma justificação legal anterior [...] A fundação de um novo sistema acontece na ausência de quaisquer parâmetros legais. Este facto torna-o, literalmente, ilegal. Uma vez que a lei conserva o monopólio da força autorizada e da força não-autorizada, a consequência é que mesmo a mais amigável inauguração de uma nova ordem legal acontece muito para além da distinção entre uso da força autorizado e uso da força não-autorizado. Derrida é cuidadoso ao sublinhar que a fundação do direito excede as fronteiras da legalidade em vez de as transgredir. É por isso que ele acredita que todos os momentos revolucionários são fundamentalmente ininterpretáveis e indecifráveis. A legitimidade da ordem legal não pode ser apresentada senão retrospectivamente, nomeadamente depois de o sistema de direito ter sido estabelecido e ser aplicável. Nesta medida, Derrida considera que a justificação moral do direito, nomeadamente a justiça, é sempre à venir, futura. (BORRADORI, 2004, p. 261-262) 
esfera do direito e da justiça (Recht, Gerechtigkeit) ou das relações morais (sittliche Verhältnisse). Não há violência natural ou física. Pode-se em linguagem figurada, falar da violência com respeito a um terremoto, ou mesmo de uma dor física. Mas sabe-se que não se trata aí de uma Gewalt que possa dar lugar a um julgamento, diante de alguma instância judicial. O conceito de violência pertence à ordem simbólica do direito, da política e da moral - de todas as formas de autoridade ou de autorização, ou pelo menos de pretensão à autoridade. E é somente nessa medida que tal conceito pode dar lugar a uma crítica. Até aqui, essa crítica se inscreveu sempre no espaço da distinção entre meio e fim. Ora, objeta Benjamin, perguntar-se se a violência pode ser um meio com vistas a fins (justos ou injustos) é proibir-se de julgar a violência ela mesma. A criteriologia concerniria então somente à aplicação da violência, não à violência ela mesma. Não saberíamos dizer se esta, enquanto meio, é ela mesma justa ou não, moral ou não. A questão crítica permanece aberta, a de uma avaliação e de uma justificação da violência em si mesma, como simples meio, e qualquer que seja seu fim (DERRIDA, 2010, p. 75).

Essas duas audições são de extrema importância, pois, como nos permite reconhecer Zizek é necessário esse passo atrás, esse nada atrás, para que nada continue no passo de que a violência deve ser apreendida apenas a partir dos seus efeitos e daquilo que nos é lançado à face. Assim também nos ensina Jacques Derrida (2010), que na sessão Do direito à justiça dentro do livro Força de lei não se cansa de nos avisar acerca da ordem, acerca da ideia de que, se nos mantivermos a observar quais seriam as críticas a serem lançadas apenas aos efeitos que a violência da ordem produz, da violência/ordem, esqueceríamos desse passo atrás, da percepção de que o lobo não se mostra, de que ele sempre está a "nada de lobo", ou seja, de que aquilo que sustenta a ordem, violência, não se mostra como tal, assim como, a violência objetiva também não se mostra. Isso pretendemos deixar claro com a relação destes pensamentos.

Então esse nada atrás, esse passo atrás que propõe Slavoj Zizek (2014) recairia na necessária distinção destes dois tipos de violência ${ }^{14}$. A subjetiva vem, se mostra, aparece, cria uma desordem, ela é um tipo de violência que abala o presente, no instante de sua aparição ela retira do lugar aquilo que "deveria" ser mantido. A violência subjetiva, portanto, é aquela que está a vista, em uma palavra, aquela que pode ser

\footnotetext{
${ }^{14}$ Uma violência subjetiva que representa a decisão, vontade, de praticar um ato violento. A violência subjetiva representa a quebra de uma situação de (aparente) não violência por um ato violento. A normalidade seria a não violência, a paz e o respeito às normas (normalidade) que é interrompida por um ato de vontade violento. A violência objetiva, diferente da violência subjetiva é permanente. A violência objetiva são as estruturas sociais e econômicas, as permanentes relações que se reproduzem em uma sociedade hierarquizada, excludente, desigual, opressiva e repressiva. (MAGALHÃES, 2012, p. 1)
} 
apreendida pelos sentidos à partida. Ela possui um efeito visual, assim como pode trazer consigo um efeito sonoro, pode trazer à tona sensações corporais internas, tanto para quem a pratica como para quem a recebe. Há um espetáculo estético nesta violência. Enquanto que a violência objetiva, de alguma forma, estruturaria esse espetáculo.

A violência subjetiva participa no cenário da ordem abalando-o. Ela destrói o cenário. A violência objetiva monta o cenário. Por isso a insistência tão grande de promoção da paz ante os assombros da violência subjetiva, porém, esse problema, essa violência, o momento em que o lobo devora a presa, quando ele uiva, quando ele ataca, quando ele faz sangrar a vítima, não é uma força da natureza, pode ser, como explicou Jacques Derrida (2010), mas ela aqui tem um sentido, ela tem uma determinação de construção. Ela é uma violência construída, constituída historicamente, esteticamente, e tanto o é, que se metamorfoseia pela história.

Esse conceito ajuda também na própria relação de direito e literatura que perpassa nossa escrita. Não bastaria, portanto, à literatura, à relação de direito e literatura, promover uma crítica a partir daquilo que são evidentemente as formas de violência subjetiva que o direito realiza. Elas permanecerão. O lobo não se tornará cordeiro. A literatura não poderia, portanto, contentar-se com um papel secundário nesse enlace. Nesse encontro do direito com a literatura, não seria possível contentar apenas em criticar a ordem, a democracia, a soberania do lobo; a proposta que lançamos e já dissemos acima, é que a cada ato desse encontro, deveríamos partir dos pontos que estamos a levantar, sobretudo, aquele que denuncia uma violência que é congênita, que não deixa vir quem a ordem não permite.

Reconhecer isso ajuda a perceber que a mesma democracia que permite essa crítica, ela, em seu coração, é violenta, é ordem e é uma democracia soberana, e a literatura, a nosso ver, não poderia servir apenas para explicitar essa violência, esse encontro deveria compor mesmo uma das chances de desconstrução dessa violência. Ela não cessará, posto que irmã siamesa da ordem, mas à literatura, como face outra, que se estrutura por outras dimensões, talvez seja importante reconhecer um papel mais protagonista: ela pode denunciar a violência subjetiva, isso é um ponto, ela pode denunciar a violência objetiva, isso também é necessário, ela reinventa a ordem deixando vir quem fora deixada à margem pelo lobo ou quem fora mesmo devorado por ele. A literatura é uma chance de dar uma volta no lobo.

Ainda não é o momento de passar a essa análise. A dimensão da violência 
subjetiva deve ser mantida em questão, porém, parece que a crítica é mais obtusa neste ponto. Assim, em maior ou menor medida, ela permanecerá, com maior ou menor exclusão, ela permanecerá. Cabe refletir como isso pode ser amainado, contudo, sem uma reflexão de fundo acerca da violência, a fala ainda se dá sob as carcaças deixadas pelo lobo após o abate. Falaremos e contabilizaremos, faremos gráficos e filmes, porém, o lobo sempre está "a passo/nada de lobo".

Enquanto não for possível essa audição, talvez a questão passe inclusive por aquilo que diz Slavoj Zizek, mesmo não sendo nosso intento acompanhá-lo para a estrada que ele indica a questão da violência: "a alta potência do horror diante dos atos violentos e a empatia com as vítimas funcionam inexoravelmente como um engodo que nos impede de pensar" (2014, p. 19). O lobo tem mesmo uma indicação de assombro, mas que por outro lado, também nos hipnotiza diante de si, o assombro diante do lobo é um momento de alienação, assim como, parece, o assombro diante da violência subjetiva também o é. É necessário um passo atrás, de novo, é necessário acompanhar aquilo que vem "a nada de lobo", seu passo, sua dimensão que não aparece, mas que comanda a cena de maneira soberana. E será importante perceber que esse poder que não aparece, essa força, essa coação e essa violência se põem em nossa leitura como a própria pele do lobo, seu passo é sempre um nada, é sempre um nada de lobo, a sua aparição é espectral, ele comanda a cena, ele não aparece na cena, mas sabe-se sempre, mesmo sem se admitir, que por detrás das cortinas há um lobo, ele tem cheiro, por vezes uiva, mas não aparece, ele está sempre "a passo (nada) de lobo". A camuflagem de lobo tem por vezes nomes os mais propagados, seja direito, seja ordem, seja democracia, chama-se até justiça!

Assim, é importante perceber que se instaurarmos a crítica apenas a partir da aplicação da violência, para falar com Jacques Derrida, e partir da violência subjetiva, para falar com Slavoj Zizek, cairíamos no problema que de alguma maneira subjaz a todo esse tópico de análise, ou seja, ainda estaríamos a tornar insuspeita a relação imbricada que há da ordem com a violência, em outras palavras, ainda estaríamos a estabelecer uma distinção entre besta e soberano, entre o lobo besta, o lobo soberano.

\section{A BESTA, O CRIMINOSO E O SOBERANO: CAMUFLAGENS}

Para que a crítica seja consistente é importante que estas duas figuras, aliás, três, da besta, do criminoso e do soberano, sejam captadas como figuras que se auto 
enviam, que se sustentam sob o mesmo sentido e a mesma mística, qual seja, a da violência que jaz dentro de cada uma delas enquanto atores sociais e a sua hipótese de “ser-fora-da-lei”. Quando Jacques Derrida põe a besta ao lado do soberano, quando ele mostra por várias leituras, que a besta é o soberano e que o soberano é a besta, o pano de fundo que sustenta estas duas figuras, a amarra que as caracteriza e que as põe no mundo atende pelo nome de violência e se mostra pelo encontro das duas em um local 'fora da lei'.

Logo, a manutenção da ordem dá-se por uma força que se auto sustenta, que seria a ausência de fundamento do direito, ou seja,

O próprio surgimento da justiça e do direito, o momento instituidor, fundador e justificante do direito, implica uma força performativa, isto é, sempre uma força interpretadora e um apelo à crença: desta vez, não no sentido de que o direito estaria a serviço da força, instrumento dócil, servil e portanto exterior do poder dominante, mas no sentido de que ele manteria, com aquilo que chamamos força, poder ou violência, uma relação mais interna e mais complexa. (DERRIDA, 2010, p. 24)

E ainda, o soberano se coloca ao lado da besta pois assim como ela, ele está na condição de uma estar fora da lei, acima da lei, na condição de quem funda, e que pode a todo/qualquer momento, voltar-se contra ela, exatamente pelo fato de a ela não se submeter $^{15}$. $\mathrm{O}$ criminoso está à margem da lei, a besta não participa desse contrato, o

\footnotetext{
15 [é] um certo poder de dar, de fazer, mas também de suspender a lei; é o direito excepcional de se colocar acima do direito, o direito ao não-direito, se é que posso dizer algo assim, aquilo que, ao mesmo tempo, se arrisca a colocar o soberano humano acima do humano, em direção à onipotência divina (que, além disso, terá fundado o mais frequentemente possível o princípio da soberania em sua origem sagrada e teológica) e, ao mesmo tempo, se mostra como a causa desse supressão ou ruptura arbitrária do direito, se arriscando justamente a fazer com que o soberano se assemelhe à besta mais brutal, que não respeita nada, que despreza a lei e se situa desde o início fora da lei, destacado da lei. Para a representação corrente, à qual nos referimos para começar, o soberano, e a besta parecem ter em comum o seu estar-fora-da-lei. É como se um e outro se situassem, por definição, destacados da lei ou acima das leis, no não respeito da lei absoluta, da lei absoluta que eles fazem ou que eles são, mas que eles não têm de respeitar. O ser-fora-da-lei pode sem dúvida, por um lado, e essa é a figura da soberania, assumir a forma do ser-acima-da-lei, e, então, a forma da própria Lei, da origem das leis, da garantia das leis, como se a Lei, com L maiúsculo, a condição da lei, fosse antes, acima e, portanto, fora da lei, exterior a ela, até mesmo homogênea em relação à lei; mas o ser-fora-da-lei também pode, por outro lado, e essa é a figura daquilo que se entende na maioria das vezes por animalidade ou por bestialidade, [o ser-fora-da-lei] pode situar o lugar onde a lei não aparece, ou não é respeitada, ou se faz violar. Esses modos do ser-fora-da-lei (seja o modo daquilo que se denomina besta, seja o modo do criminoso, até mesmo desse grande criminoso [...] do qual Benjamin dizia que ele fascina as multidões, mesmo quando o condenamos e executamos, uma vez que ele desafia, com a lei, a soberania do Estado em seu monopólio da violência, seja ainda mesmo o ser-fora-da-lei do próprio soberano), esses diferentes modos de ser-fora-da-lei podem parecer heterogêneos entre eles, até mesmo podem ter a aparência de serem heterogêneos em relação à lei. Apesar disso, ao partilharem esse ser-fora-da-lei comum, a besta, o criminoso e o soberano se assemelham de uma maneira perturbadora; eles se convocam e evocam entre si, uns aos outros [...] Todos os dois, todos os três, o animal, o criminoso e o
} 
soberano é a face do contrato, a face que está sempre na condição privilegiada de negála, refundá-la em mais um ato violento, que é aquilo que ele oferece, por ser aquilo que o constituiu enquanto tal.

Portanto, é importante um passo atrás. Esse passo atrás permite apreender o conceito de violência objetiva de Slavoj Zizek que ele desdobra ainda em mais duas dimensões que importam aqui e mais ainda, importarão para a própria relação que se fará logo adiante entre direito e literatura. Não nos adiantemos. O lobo não aparece. Por que disso ${ }^{16}$

É que esse lobo, que é o soberano, participa do jogo sempre "a passo de lobo", “a nada de lobo". Assim, não há vulgarmente um reconhecimento de que a ordem, aquilo que é soberano é da mesma ordem do lobo, da besta, do criminoso, isso porque, eles estão na mesma condição de "ser-fora-da-lei", cada um sob sua hipótese, todos sob/sobre/fora do mesmo local, portanto, quando se aproximam essas figuras, que andam sempre "a passo/nada de lobo", o nada do "pas" interessa fortemente, porque nesse nada de lobo se esconde, escamoteia a presença do lobo, e nisso reside sua força, seu problema e sua mística. Assim as injustiças/violências subjetivas, que vem à tona e que foram cometidas pela ordem, não são nada mais do que a excrecência daquilo que ela em si carrega, ou seja, o lobo é lobo.

A ordem é soberana. A besta é o soberano. A ordem é o lobo. Por isso, seus atos, mesmo que sob a pele de cordeiro, de novo as expressões, "lobo sob pele de cordeiro", lancem à compreensão da própria violência objetiva de Slavoj Zizek (2014) e permita reconhecer que a ordem não se mostra violenta, ao contrário, em pele de cordeiro, sob os inúmeros adjetivos que ela carrega - democracia, justiça, etc - ela sempre estará escamoteada, ela não pode mostrar sua face verdadeira, a face de/do lobo,

soberano são foras da lei, estão apartados das leis ou acima das leis; o criminoso, a besta e o soberano se assemelham estranhamente, por mais que eles pareçam situar posições antipódicas, por mais que eles pareçam ser antípodas uns dos outros. (DERRIDA, 2016, p. 37-39)

${ }^{16}$ Em todo caso, nos dois casos de diferença sexual "passo de lobo / "nada de lobo" significa a ausência, a não apresentação literal do próprio lobo ao chamado do seu nome, portanto, a sua única evocação figural trópica, fabulosa, fantasmática, conotativa: não há lobo, há "passo de (nada) lobo". E a ausência desse lobo intangível em pessoa diferentemente daquilo que acontece segundo uma fábula, essa ausência diz ao mesmo tempo o poder, o recurso, a força, a artimanha, a artimanha da guerra, o estratagema ou a estratégia, a operação de domínio. O lobo é mais forte, a significação de seu poder é mais aterrorizante, armada, ameaçadora, virtualmente predatória do que nesses chamados, do que nessas locuções, o lobo ainda não aparece em pessoa, mas apenas na persona teatral de uma máscara, de um simulacro ou de uma palavra, ou seja, de uma fábula ou de um fantasma. A força de lobo é tanto mais forte, até mesmo soberana, ela tem tanto mais razão porquanto o lobo não está aí, porquanto não há o lobo ele mesmo, à exceção de um "passo (nada) de lobo", exceto um "passo (nada) de lobo", salvo um "passo (nada) de lobo", somente um "passo (nada) de lobo". (DERRIDA, 2016, p. 23-24) 
que seria o oposto dela, mas que pretendemos mostrar, de tão avessa, que se quer tão avessa, se preferi, de tanto que se quer distanciar, acaba por se encontrar naquilo que as une: a violência.

\begin{abstract}
A questão é que as violências subjetiva e objetiva não podem ser percebidas do mesmo ponto de vista: a violência subjetiva é experimentada enquanto tal contra o pano de fundo de um grau zero de violência. É percebida como uma perturbação do estado de coisas "normal" e pacífico. Contudo, a violência objetiva é precisamente aquela inerente a esse estado "normal" de coisas. A violência objetiva é uma violência invisível, uma vez que é precisamente ela que sustenta a normalidade do nível zero contra a qual percebemos algo como subjetivamente violento. Assim, a violência sistêmica é de certo modo algo como a célebre "matéria escura" da física, a contrapartida de uma violência subjetiva (demasiado) visível. Pode ser invisível, mas é preciso leva-la em consideração se quisermos elucidar o que parecerá de outra forma explosões "irracionais" de violência subjetiva. (ZIZEK, 2014, p. 17-18)
\end{abstract}

Invisível. "A passo (nada) de lobo". O intento que move aqui é o de deixar claro que a dimensão da violência objetiva seria o ponto a ser descoberto. E para isso foi necessário mostrar que quando falamos do lobo, da ordem, do direito, não é possível deixar de levantar como ela se move, ou seja, a ordem, assim como o lobo, sempre está "a passo (nada) de lobo", e desculpem-nos a insistência. A violência objetiva, aquela que mantém o que se chama ordem, normalidade, direito, não se apresenta enquanto violência, ao contrário, dá-se como medida da violência, ela, soberana, indica o que está fora, dentro e à margem da lei. Isso exatamente para não deixar a nu sua face, que também ali se coloca. Criticar a violência subjetiva seria, portanto, o próprio mote de que se vale a ordem, ela evidencia, faz teatro dela, expõe, contabiliza, exatamente para chegar como soberana, como aquela que traz a paz. Para isso, Jacques Derrida (2010), ao início do seu seminário nos mostra que a pomba, que simboliza a paz, também chega sempre "a passo de pomba", quer dizer, o mesmo passo do lobo é o passo da pomba. Poderíamos até dizer, lobo em pele de cordeiro/de pomba, ou pombo. Assim, nada de pomba, porquanto estivermos assentes sob a firma de que quem diz da paz, antes promove a guerra, ouçamos de novo Slavoj Zizek (2014, p. 18): "Pode ser invisível, mas é preciso leva-la em consideração se quisermos elucidar o que parecerá de outra forma explosões "irracionais" de violência subjetiva."

Assim, de pronto, quem diz da ordem, diz da violência da ordem. Quem diz do 
direito que sustenta a ordem, diz do direito que se funda na violência. Essa violência objetiva que opera orquestrando a ordem seria o próprio fundamento dela. Ela se arroga na soberania de si para "organizar" a sociedade. E é exatamente aí que são semeados os frutos que reluzirão depois enquanto violência subjetiva - o sucedâneo da violência objetiva, seu fruto, sua consequência.

Aludir a estas dimensões, da besta soberana e da ordem junto da violência objetiva, em nossa dicção, é aludir à mesma coisa. A maneira como ela se dá seria tema para outra discussão que aqui não cabe. Necessário é deixar assente que não haverá hipótese de uma crítica proveitosa da violência sem que compareça esta dimensão dela mesma. Olvidar a essa crítica é com se permanecêssemos crentes naquilo que diz o lobo. Seria não desconfiar de seu passo, de seu nada. A sua ausência, seu nada, aquilo que não se pode ver e que Slavoj Zizek adjetivou de invisível é o que sustenta sua determinação, sua força de coação, é dizer, aquilo que sustenta a sua aceitação sem questionamentos.

Por isso o lobo não pode mostrar sua face. Por isso foram escritas páginas e páginas sobre como a democracia e o direito poderiam e deveriam ser realizados. Parece que qualquer análise sobre a ordem que não tenha em conta o seu gene criador e, portanto, sua força de perpetuação enquanto ordem, sua violência, esquiva-se ao coração do problema, aquele que mostra a face esguia do lobo. Seria como se nos colocássemos à caça do lobo sem perceber duas coisas: colocarmo-nos à caça do lobo, querer ser dele soberano, nos coloca extremamente aproximados dele, mostrando a necessidade assim da própria desconstrução, por outro lado, descuidar da violência objetiva seria talvez uma ingenuidade, ou pior, uma perversidade, pois essa caça não mostra outra cosia senão o medo da ameaça de perda da soberania. $\mathrm{O}$ direito, quando atua, está ali a se precaver de si mesmo, a ordem sabe que ela é o lobo, ela, portanto, necessita proteger-se, não das violências subjetivas, que a mais das vezes ela neutraliza sob a alcunha da criminalidade em geral, não do que está a mostra, mas, proteger-se de si mesma, para continuar sua estrada, para não mais ser ameaçada. Expliquemos melhor.

$\mathrm{O}$ direito é violência. $\mathrm{O}$ direito age com violência. $\mathrm{O}$ lobo é violento. Age com violência. Age como "foras da lei", ditos, criados, pelos limites que a ordem coloca. Assim, quando ele se volta contra os abalos que os criminosos provocam, ele não estaria a se preocupar com outra coisa senão com a sua própria manutenção. A violência do lobo, trasvestido de criminoso, coloca em xeque a ordem soberana, ela precisa se 
defender, e o faz, não sem outra face, besta. A "besta objetiva" abafa, ataca, procura aniquilar qualquer ameaça da "besta subjetiva".

De outro lado, em uma ordem de direito, os cidadãos e cidadãs, têm direito a direitos, porém, quando esses direitos que lhes são garantidos, aparece a questão com mais clareza, quando estes cidadãos e cidadãs, que apenas o são dentro da ordem, ameaçam-na, então a ordem volta-se contra eles. O lobo, quando ameaçado, ataca, porém, isto é apenas a dimensão visível do lobo, ele age, como já dito, sempre a passo de lobo, o seu nada, aquilo que não mostra, é sua face perversa e o que ele é, que comanda o espetáculo democrático, que dá a ele esse nome, mas que também o assegura, e assegurar que ele não se perca, que ele se mantenha em ordem, é a própria dimensão de besta que escancara Jacques Derrida.

Hanna Arendt diz haver o direito a direitos, enquanto Jacques Derrida nega haver direito ao direito. Parece que isso reafirma a questão: sempre que houver uma ação que indique essa vontade de direito, essa intenção, por exemplo, como a questão da greve que já foi trazida, a ordem volta-se violentamente contra aqueles que estão a requerer esse direito ao direito. Isso constitui talvez um momento em que o lobo apareça, saindo de sua dimensão de nada de lobo. Porém, e a questão parece não ter fím, quando a ordem se insurge contra aqueles que clamam pelo direito ao direito, percebam a palavra no singular, ela aparece de forma violenta, por evidente, logo, é nesse momento de suspensão de si que o lobo mostra sua face de ser-fora-da-lei. No limite, ele aparece dessa maneira, mas outra vez, como um outro tropo ${ }^{17}$, ele vem "a passo (nada) de lobo" porque agora a justificativa é que sua ação fundar-se-ia na necessidade de manutenção da ordem. E assim sucessivamente. Estamos na ordem, a ordem é forada-lei, o lobo é fora-da-lei, a ordem captura o lobo, a ordem cria o cativeiro para o lobo. O lobo ameaça a ordem, ela elimina este lobo, reaparece, sem aparecer, "a passo (nada) de lobo" com outra roupagem. Por isso acima foi dito que o lobo confunde seu habitat consigo mesmo. Ele se mistura com ele e camufla-se de acordo com o local, o tempo e o modo necessários para não perder sua dimensão de soberania, de lobo, de ordem jurídica. ${ }^{18}$ Ele não deixará de ser lobo. Seja em pele de lobo, seja em pele de cordeiro,

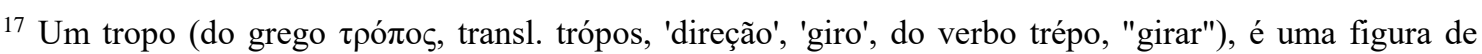
linguagem ou da retórica onde ocorre uma mudança de significado, seja interna (em nível do pensamento) ou externa (em nível da palavra).

${ }^{18}$ Em outros termos, mostra-nos Zizek essa força que está sempre a fazer o lobo manter-se ali, a violência objetiva se camufla em si, se camufla em outros nomes para absorver/comer aquilo que a ameaça, engole e renasce em outras peles, em outras vestimentas, outros nomes; estado democrático de direito,
} 
mas sempre é garantido que virá "a passo (nada) de lobo". Acredite nessa fábula quem quiser. E para que fique assente, importa apenas relembrar que a relação da ordem, do direito, no início da leitura de Força de Lei resta aqui aclarada, esperamos.

Há-de-vir é uma boa expressão para dizer disso, o verbo haver aqui se mostra no presente do indicativo, "ele há", aliado à preposição "de" que com o verbo "vir" dá uma impressão muito precisa do que se quer dizer, ou seja, aquilo que há-de-vir ao mesmo tempo já chegou e nunca deixará de chegar, pois, o "há" denota um estado de presença, mas de outro lado, o vir lança essa presença adiante em constante diferenciação dela consigo mesma e que mantém um continuum na língua não deixando desgarrar o que está do que vem. Logo, o lobo sempre é um há-de-vir, que está, sem se mostrar, posto que vem, que vindo, "a passo (nada) de lobo". Há na camuflagem do lobo também essa hipótese. Ele quando dá uma volta na ordem para assegurar seu poderio, também se esconde nesse tropo. Daquilo que está, porém, sempre com vistas a chegar. Ele está na ordem, sai dela, torna-se fora-da-lei, mas sempre apontando para um futuro "melhor", mais ordeiro e assegurado de quem turba a ordem. O lobo é uma figura que se esquiva da presença, ele é a própria esquiva. Por isso, acreditemos nas fábulas. Acreditemos nas fábulas! Acreditemos nas fábulas?

\section{VIOLÊNCIA E LITERATURA: É POSSÍVEL DAR A VOLTA NO LOBO?}

A violência subjetiva, esse móbil evidente de violência manifestada é possibilitada por uma violência estrutural que tem como efeito aquela primeira. Bom, quanto a isso parece que restamos assentes, a questão que importa agora e para a qual

\footnotetext{
democracias, são peles constantes que revestem e escondem o que vimos insistindo que sempre se dá "a passo (nada) de lobo": Na última década, Davos e Porto Alegre afirmaram-se como as duas cidades gêmeas da globalização. Davos, uma exclusiva estância turística na Suíça, é o lugar onde a elite global dos gestores, políticos e personalidades midiáticas se encontram sob pesada proteção policial, em condições de estado de sítio, e tentam convencer-nos e a si próprios de que a globalização é o melhor remédio para si mesma. Porto Alegre é a cidade brasileira subtropical onde a contraelite do movimento antiglobalização se reúne em assembleia e tenta convencer-nos e a si própria de que a globalização capitalista não é uma fatalidade para nós, pois - como sua palavra de ordem oficial proclama - "um outro mundo é possível". Ao longo destes últimos anos, no entanto, as reuniões de Porto Alegre parecem ter perdido parte de seu ímpeto. Cada vez menos ouvimos falar delas. Onde foram parar as cintilantes estrelas de Porto Alegre? Algumas delas, pelo menos, foram para em Davos. O tom que prevalece cada vez mais nas reuniões é o de um grupo de empresários - alguns dos quais se designam ironicamente como "comunistas liberais - que já não aceita a oposição entre Davos (o capitalismo global) e Porto Alegre (a alternativa ao capitalismo veiculada pelos novos movimentos sociais). Sua tese é de que podemos ter o bolo capitalista global (ou seja, prosperar como empresários de sucesso) e ao mesmo tempo comê-lo (aprovar as causas anticapitalistas de responsabilidade social e a preocupação ecológica). Dessa forma, Porto Alegre deixa de ser necessária, uma vez que Davos pode transformar-se em Porto Davos. (ZIZEK, 2014, p. 27-28)
} 
chamaremos à discussão Roland Barthes em sua Aula é a de mostrarmos como essa estrutura violenta, esse lobo que porventura não se mostra, atuaria na dimensão da linguagem.

Nessa dimensão de abordagem, nesse passo atrás que vimos insistindo, encontramos com aquilo que ele chama uma violência "simbólica" e que viria involucrada naquilo que nos permite o encontro com o outro, a linguagem ${ }^{19}$.

Neste caso haveria na linguagem uma coação para um determinado horizonte de sentido que seria nela perpetrado e que engendraria com isso também uma série de violências. Contudo, para além dessa dicção, importa-nos agora um diálogo com Barthes para procurarmos aclarar a questão e darmos um passo mais em nossa escrita acerca da relação de direito e literatura. Ao início de sua Aula, Roland Barthes (1988) já nos lança ao coração da questão que envolve a linguagem e que de alguma maneira viemos margeando até aqui. Diz-nos que é de poder que irá tratar nesta aula. Já aludimos à questão do poder. A instauração de um poder dá-se sempre pelo médium da violência, quer ela se apresente, quer não.

A questão posta é da ordem de uma reflexão acerca da própria soberania, seja ela exercida da maneira que for, porque a ideia do poder e da soberania está sempre aliada, e precisa disso, com uma ideia de subordinação, apropriação, em outras palavras, a soberania e o poder necessitam daquilo que Barthes chama dos discursos de poder.

Discursos de poder como discursos da imposição de um poder. O soberano sempre está em condições de proclamar um discurso de poder. O direito, como lobo, se faz presente no próprio discurso de poder. Ele se arroga na condição de quem diz a lei, e quem diz a lei, também é quem determina quem fica e quem sai da lei, quem são os fora-da-lei.

O encontro de Slavoj Zizek e Roland Barthes que aqui promovemos talvez conduza um pouco mais a fundo na reflexão, pois, quando Slavoj Zizek solicita um passo atrás em relação à violência, faz de maneira tal a afirmar que na linguagem haveria uma violência simbólica; Roland Barthes, por seu turno, informa que a própria linguagem seria já uma legislação que possui na língua o seu código. Essa assertiva

\footnotetext{
${ }^{19}$ Em primeiro lugar, há uma violência "simbólica" encarnada na própria linguagem e em suas formas, naquilo que Heidegger chamaria a "nossa casa do ser" [...] essa violência não está em ação apenas nos casos evidentes - e largamente estudados - de provocação e de relações de dominação social que nossas formas de discurso habituais reproduzem: há uma forma ainda mais fundamental de violência que pertence à linguagem enquanto tal, à imposição de um certo universo de sentido. (ZIZEK, 2014, p. 17)
} 
lança, portanto, as questões que gostaríamos de tentar elucidar aqui. Se a língua é essa mostra de poder, de opressão à qual estamos lançados na relação com outro, ela seria esse lobo que nos permite o encontro e também que nos obriga ao encontro? A linguagem portaria essa violência simbólica que resta esquecida uma vez que se perde a noção de que toda língua seria uma classificação e que toda classificação seria opressiva: "ordo quer dizer, ao mesmo tempo, repartição e contaminação. Jakobson mostrou que o idioma se define menos pelo que ele permite dizer, do que por aquilo que ele obriga a dizer." (BARTHES, 1988, p. 6)

A língua é, portanto, lobo, fascista em palavras de Roland Barthes (1988). Dizse que o humano o é na linguagem. Somos lobos toda vez que estamos a manejar a língua em relação ao outro? Somos cordeiros na medida em que a língua "obriga-nos a dizer"? Ou ela é que nos faz lobos e cordeiros? Essa soberania impõe-se exatamente pela sua força classificatória, pela força de constante apreensão do outro e da outra que requer a língua. Mas se assim o é, se estamos sempre nessa dimensão de apropriação do outro por força da linguagem, se ao mesmo tempo somos lobos e cordeiros ante a língua $^{20}$, restariam aqui encerradas as coisas? A fala de Barthes de que só haveria liberdade fora da linguagem significaria que é preciso matar o lobo, em mais de um ato de linguagem, mas como caminhar fora da linguagem? Há essa hipótese?

Nesta estrada de reflexões o que importará propriamente será mostrar que estamos por assim dizer condenados à língua. Condenados a morrer e a viver, pois se de um lado a língua obriga e oprime a estarmos nela, de outro, é ela também aquela capaz de oferecer uma redenção. O que chamamos redenção seria o mesmo dizer que ela oferece uma saída. Haverá uma saída, no entanto, e isso interessa imensamente, a língua só oferece a saída nela mesma, a partir dela e mais precisamente na travessia dela ${ }^{21}$.

Atravessar a travessia da língua. O trânsito a que nos entregamos por estarmos

20 Em nossa língua francesa (e esses são exemplos grosseiros), vejo-me adstrito a colocar-me primeiramente como sujeito, antes de enunciar a ação que, desde então, será apenas meu atributo: o que faço não é mais do que a consequência e a consecução do que sou; da mesma maneira, sou obrigado a escolher sempre entre o masculino e o feminino, o neutro e o complexo me são proibidos; do mes mo modo, ainda, sou obrigado a marcar minha relação com o outro recorrendo quer ao $t u$, quer ao vous; o suspense afetivo ou social me é recusado. Assim, por sua própria estrutura, a língua implica uma relação fatal de alienação. Falar, e com maior razão discorrer, não é comunicar, como se repete com demasiada frequência, é sujeitar: toda língua é uma reição generalizada. (BARTHES, 1988, p.6, grifo nosso)

21 A ordem instituída e a regularidade são um princípio de morte instalado na vida. Para vencê-lo devemos produzir um excesso, transtornando ao máximo a continuidade, isto é, erotizando o movimento regrado. Provocando o imprevisto. O erotismo é um excesso de imprevisibilidade. É a descontinuidade significando-se. É a forma de tentar vencer o pavor do imprevisível. (WARAT, 1985) 
desde sempre nela, por ela nos obrigar a falar. Mas, na mesma dimensão da entrega, no mesmo momento em que somos obrigados e "devorados" por ela, nesse fascismo que se impõe, a língua abre a nós, em seu anverso, no seu verso, entanto, nela mesma, uma hipótese de saída. Logo, ao que parece, não trata de procurar um local no qual encontrar uma língua que fosse dada de maneira não violenta, ou seja, como permite Roland Barthes (1988), as classificações dadas à linguagem, se reacionária ou progressista, tratar-se-iam de meras injunções uma vez que a língua nos obriga. Neste sentido, permanecemos dentro dela, na mata que nos envolve, dentro do território do lobo, no jogo dele.

A essa afirmação de entrar na dança do lobo, de dançar com ele, aponta para o próprio conceito de literatura cunhado por Barthes e que gostaríamos de apresentar como maneira de elucidar a hipótese de saída/entrada desse jogo. A língua mostra sua face de lobo cada vez que é pronunciada. Não há relacionamento sem essa dimensão. Somos lobos, porém, mais ainda, cordeiros, uma vez que a língua nos abocanha os calcanhares sempre que somos por ela interpelados. A interpelação, o momento da interpelação pela língua é um momento violento sempre. Logo, qual a saída/entrada? Como se daria uma dança com o lobo? Com a loba, a língua que envolve, que engole, dá a vida e retira também?

Mas a nós, que não somos nem cavaleiros da fé nem super-homens, só resta, por assim dizer, trapacear com a língua, trapacear a língua. Essa trapaça salutar, essa esquiva, esse logro magnífico que permite ouvir a língua fora do poder, no esplendor de uma revolução permanente da linguagem, eu a chamo, quanto a mim: literatura. (BARTHES, 1988, p. 8$)^{22}$

\footnotetext{
${ }^{22}$ E não nos parece distante da trapaça suscitada por Barthes, o que Derrida nos ensina acerca de uma explicação muito particular de sua iterabilidade. Essa libertação, diríamos, dos significados transcendentais ou dos sentidos determinados que evidenciam uma verdadeira trapaça que Derrida comete dentro da língua ao dizer que a iterabildiade mostraria, portanto, a possibilidade da legibilidade do texto e, na mesma tacada, a impossibilidade de qualquer determinação a priori, seja do significado, seja do contexto que guardaria o significado: "Isso se deve à estrutura de um texto, ao que chamarei, para ser sintético, sua iterabilidade, que, a um só tempo, finca raízes na unidade de um contexto e, imediatamente abre esse contexto não saturável para uma recontextualização. Tudo isso é histórico do começo ao fim [...]" Dizer que uma marca ou que um texto são originariamente iteráveis é dizer que, sem terem uma origem simples e, portanto, sem uma "originalidade" pura, eles se dividem e se repetem de imediato. Tornam-se, portanto, capazes de ser desarraigados no próprio lugar de suas raízes. Transplantáveis para um contexto diferente, continuam a ter sentido e efetividade. Não que o texto seja desse modo des-historicizado, mas a historicidade é feita de iterabilidade. Não há história sem iterabilidade e essa iterabilidade é também o que permite aos rastros continuarem a funcionar na ausência do contexto geral ou d alguns elementos do contexto. (DERRIDA, 2014, p. 97-98)

"Quando ao "redizer" [redite], o núcleo lógico da coisa - e insisti muitas vezes nisto - é que não há incompatibilidade entre a repetição e a novidade daquilo que difere. De maneira tangente e elíptica,
} 
É interessante como Barthes desenvolve seu raciocínio pelas figuras de linguagem que usa, que são próprias daquelas que já nos referimos, "entendo por literatura não um corpo ou uma sequência de obras, nem mesmo um setor de comércio ou ensino, mas o grafo complexo de pegadas de uma prática: a prática de escrever" (BARTHES, 1988: 8, grifo nosso). Logo, mais uma vez estamos "a passo (nada) de lobo", agora para mostrar que aquilo que instaura o mundo, que conduz ao outro, se dá também de maneira violenta. Essa dicção quer informar que a dimensão da língua é uma dimensão violenta da língua, pois ela é soberana, e não haveria maior soberania do que aquela que se dá no local em que habitamos. O passo atrás de Slavoj Zizek, esse nada que já informou Jacques Derrida, torna agora explicitado pelo ensinamento de Barthes. Não haverá local em que desde sempre não estejamos já na senda, na pegada, no passo do lobo.

"A passo (nada) de lobo". Desde Jacques Derrida e Slavoj Zizek não se pode mais descuidar desta questão, da questão soberana e também da questão do poder, dos discursos de poder. Como se trabalha com a língua, uma vez que ela está sempre ali, aqui, a nos obrigar, a me obrigar a dizer dela, sempre dentro de suas regras; propomos, junto de Barthes, a hipótese da literatura como essa trapaça, um trabalho de esquiva, um trabalho de desvio. Esse desvio, mais ainda, um desvio como local de invenção, é o local em que pensamos encontrar o direito com a literatura ${ }^{23}$.

\footnotetext{
uma diferença faz sempre desviar a repetição. Chamo a isto iterabilidade, o surgimento do outro (itara) na reiteração. $\mathrm{O}$ singular inaugura sempre, acontece mesmo, imprevisivelmente, como o que está a acontecer mesmo, através da repetição. Enamorei-me recentemente da expressão francesa "une fois pour toutes" [à letra: uma vez para todas, N.T.] (creio que é intraduzível, mas deixemos isso). Esta expressão diz de maneira muito económica o acontecimento singular e irreversível (daquilo) que não acontece senão uma vez e, portanto, já não se repete, mas ao mesmo tempo abre todas as substituições metonímicas que o arrastarão para outros lados. $\mathrm{O}$ inédito surge, quer se queira que não, na multiplicidade das repetições. Eis o que suspende a oposição ingénua entre tradição e renovamento, memória e porvir, reforma e revolução. A lógica da iterabilidade arruína de antemão a segurança de tantos discursos, filosofias, ideologias [...] Isso faz-me pensar em Jacues Houssoun, psicanalista, que tinha trabalhado sobre a maneira como Cristovão Colombo encarara a sua viagem às Índias. Tinha por objetivo descobrir um novo tajecto para as Índias. De facto, logo que chegou à América, definida como tal muito mais tarde, não descobriu algo de novo senão porque queria repetir o caminho das índias [...] (DERRIDA; SPIRE, 2008, p. 15-16)

${ }^{23}$ Sedução da errância, a Literatura confere ao Sujeito o direito de transformar o espaço da página em página do mundo, incidindo no desenho de comunidades simbólicas que se fazem o lugar primeiro de diálogos disciplinares. Multiplicador, o Sujeito colhe dos saberes disseminados a própria irradiação da subjetividade. "Ni passeur [...] ni passante", no entanto, segundo Derrida, atua no espaço intervalar (e novo) produzido pelo entrecruzamento de territórios simbólicos; paradoxal mas complementar, o Sujeito faz-se mediador de certa configuração plural: se, por um lado, experimenta a sensação de estar fora do lugar (Fora do lugar constituindo o título de uma obra de Edward Said), de outro, é dessa profunda percepção que colhe a certeza da autotradução. (SILVA, 2013, p. 29)
} 
O direito é, portanto, discurso do poder, pois vem sempre carregado e carreado por essa dimensão de soberania, dá-se sempre em uma dimensão adversária de intersubjetividade. Quer a todo momento provar e dar prova de si. É um lobo faminto a todo momento. Dois lobos diria, um, aquele da língua, o outro, aquele que se esconde dentro da língua e maneja seus passos em direção à presa. Qual a hipótese se poderia levantar desse encontro entre a matilha do direito, sua força, sua soberania, com a literatura?

À partida, e isso se dá aqui apenas à guisa de anunciação do que vem, pensamos que desse encontro do direito com a literatura o que subjaz estará acompanhado dos ditos de Barthes; não haveria que se criar uma linguagem outra, essa possibilidade ainda não apareceu, portanto, resta essa trapaça. E é muito importante usar o termo trapaça, desvio, porque sempre o soberano quer tomar o outro à sua própria medida. E quem trapaceia, que devia, é sempre aquele que sai da lei, aquele que escapa à lei, o soberano, como já vimos, não admite isso, insistimos, não por uma força de benevolência, "lobo em pele de cordeiro", mas exatamente pelo temor que possui de ser ameaçado em sua soberania.

A língua é soberana. Não há chance para essa fuga, esse tropo, sem que se esteja nela. A saída/entrada que Barthes oferece dá a literatura, a oportunidade de que aquele que vem, de um outro ou outra que vem, não restarem desde sempre engolidos pela ordem talvez esteja também nesta mesma estrada. Nas pegadas da prática literária restaria essa chance. A hipótese da literatura não se daria entanto como uma salvação, não é disso que se trata. Da mesma maneira, iremos aprofundar isso adiante, que a literatura nesse momento de encontro com a matilha do direito, com a matilha que é a ordem, possa oferecer chegada para o desvio, o desviante, o desviado dela. Seria ela esse desvio mesmo. Isso por algumas questões que importa mais uma vez reafirmar.

O cálculo que é a maneira como o direito se mostra dá-se sempre em uma medida pré-determinada, recheada de convenções e códigos que delineiam a estrada por onde a matilha irá passar. A justiça, de outro lado, como já mostramos, caminha sempre em uma dimensão do excesso, de uma aporia que reclama, perquiri, mostra outras estradas, outros rumos, em uma palavra, a justiça é uma dimensão do impossível que não deixa com que as coisas restem sempre dadas, ela se impõe como a senda aberta, desvia - quer desviar - o itinerário pré-estabelecido. Traz para o seio da segurança jurídica a "insegurança" de uma alteridade, de uma singularidade. 
$\mathrm{Na}$ ordem do cálculo nunca haverá justiça. Mas essa fala a despeito de entendimentos equivocados, se põe como um ato necessário, até mesmo, é ela que permitirá qualquer justiça. Não há justiça no direito, somente uma justiça enquanto direito, esse assombro do impossível mostra a necessidade da discussão acerca da ordem, deixa aberta a hipótese ao que vem, a justiça impossível é o ouvido do direito.

A literatura, tal como posta por Roland Barthes (1988), tem a possibilidade de invenção. $\mathrm{O}$ ato de desvio, o ato de trapaça são atos de invenção sempre. Isso porque ele deixa vir quem não estava $\operatorname{ali}^{24}$. O discurso de poder que se impõe enquanto ordem é nele mesmo, a partir dele e dentro dele, trapaceado quando posto em contato com a literatura. Esse desvio significa também uma parada, uma interrupção da ordem corrente das coisas; uma das maneiras como a violência se mostra, sem mostrar, "a passo (nada) de lobo" é exatamente assegurar que tudo corra, que tudo esteja a fluir, na maior normalidade.

O excepcional vem sempre a abalar essa ordem, o excesso, normalmente não têm lugar na ordem. Devem ser combatidos, devem ser expurgados. Neste sentido, a literatura traz para a selva ordenada do direito aquilo que a ordem chama de "fora-dalei”, porém, importa reafirmar: quem diz a ordem? O soberano. Quem diz o que não cabe na ordem? O soberano. Quem diz quando há e não há ordem? O soberano. Quem sai da ordem para refunda-la e justificar a necessidade da paz por exemplo? O soberano.

E a língua impera sobre o humano. Ela também o funda. Ela instaura o humano no mundo. Daí que a língua aqui também compareça como uma força soberana. Ela também é besta. Quando a ordem se apodera de seu discurso de poder ela está vestida sob a pele da soberania, que é a pele do lobo, que está sempre ali, na sanha de apropriação que lhe é inerente pela força que a constitui. Não podemos ser senão na linguagem. Mas essa obrigação, essa coação que a língua nos impõe e que nos obriga a falar sempre estará ali. A língua, portanto, seria também um fora-da-lei, à maneira do soberano, a língua soberana que nos obriga a ela. Que requer que estejamos em

\footnotetext{
${ }^{24}$ Avançando nesta perspectiva podemos dizer que as verdades jurídicas precisam estar sempre atraídas pelo caos, desafiando a tentação suicida da linguagem. Sempre vale mais um suicida que um zumbi. "Jazz-verdades" talvez seja a chave para transformar uma arcaica vontade de verdade em uma vontade de criação, mostrando a atmosfera dos desejos. A vida renasce nas artes [...] Nosso cotidiano nos exige diariamente respostas palpitantes. Para desenquadra-lo nos moldes rotineiros precisamos saltar o limite, mergulharmos no espaço que nos foi distraidamente concedido. Nesta tarefa as ciências sociais andam pouco. O reconhecimento da realidade pela teoria não dá o mergulho. $O$ salto à ação exige reconhecimento e a vivência da realidade como poética. $\mathrm{O}$ desejo também é poesia: o halo significativo do Jazz. (WARAT, 1985, p. 47)
} 
movimento nela, que permite os discursos de poder. Mas que permite também a literatura.

A saída do poder, do discurso do poder, sua denúncia, são tentativas de dar uma volta no lobo. Sem saída da língua, o encontro do direito com a literatura, pode talvez ser um ato inaugurador daquilo que vem, de uma dimensão de alteridade que resta inaudita pelo lobo, provável que se deixarmos as coisas como estão, sempre seja, mas é sempre na hipótese da desconstrução como justiça que queremos falar. De uma desconstrução que esteja alojada na travessia que propomos com a literatura ante do discurso do poder. Pudemos dizer com Guimarães Rosa que pode-se até mirar um ponto de chegada, mas certamente ao fim da travessia, iremos aportar em local outro. Esse outro local, esse local ainda não visto, esse local que a ordem não deixa chegar, chamamos literatura, ou em melhores palavras, o humano como literatura. Essa hipótese dar-se-ia, portanto, se admitida a literatura em seu caráter desviante, que diz do que não está à mão.

Eu dizia há pouco, a respeito do saber, que a literatura é categoricamente realista, na medida em que ela sempre tem o real por objeto de desejo; e direi agora, sem me contradizer, porque emprego a palavra em sua acepção familiar, que ela é também obstinadamente: irrealista; ela acredita sensato o desejo do impossível. Essa função, talvez perversa, portanto feliz, tem um nome: é a função utópica. (BARTHES, 1988, p. 11)

Podemos lembrar Jonh Caputo ao dizer que importa irmos onde não podemos ir $^{25}$. A ordem, o direito, são da dimensão do cálculo, a literatura traz para dentro do direito essa chance de ir onde ele não vai. É importante notar que estamos aqui a trabalhar no terreno e com as mesmas ferramentas que se vale o lobo, ademais, o soberano sai da ordem para fundá-la, se põe acima das leis sempre que a vê ameaçada; no mesmo passo, a literatura como fonte de hospitalidade e invenção, reinauguraria a ordem a cada ato de encontro de si com o direito. É uma chance ${ }^{26}$, não uma necessidade.

\footnotetext{
${ }^{25}$ Uma das formulações a considerar é que a literatura ajuda a pensar o impensável, aquilo que nem a própria filosofia muitas vezes dá conta. (NASCIMENTO, 2014)

${ }^{26}$ A leitura, portanto, abre alguém a chance de refletir sobre o modo pelo qual qualquer identidade ou ontologia dada ou presumida é apenas um vir-a-ser, uma momentânea colocação ou ocasiões de traços que traçam e são traçados, abrindo o significado ou o presente à assustadora instalação. Mais do que isso, percebendo a inelutável tradução do eu através de seu tornar-se, alguém pode refletir que onde alguém está [...] é marcado, determinado momentaneamente pela secreta chegada de um outro que ocorre na leitura [...] O que permanece não lido, portanto, não é aquilo que o futuro sustenta como a promessa final de fechamento da leitura. É aquilo que está sempre por vir, sempre vindo a qualquer momento dado de leitura. Dentro de qualquer presente ou presença, existe o outro, o revenat assombrador. Este é o segredo da literatura. (WOLFREYS, 2009, p. 58-59)
} 
É uma hipótese de dar essa volta, de estar junto e ao mesmo tempo infectando o lobo, não para acabar com ele, isso não seria possível, mas de maneira tal a reinventá-lo. A essa reinvenção democrática ${ }^{27}$, a esse espaço de invenção, a esse momento de suspensão da ordem, não de fora, mas de dentro, chamaremos fonte constante de hospitalidade e invenção ${ }^{28}$.

\section{LITERATURA VADIA? CONCLUSÃO(?)}

Ainda junto da proposta de Roland Barthes (1988), de uma maneira de darmos uma volta no poder, e é importante mencionar a questão desse círculo. Não como algo que se fecha em si, mas que como o Aleph de Jorge Luis Borges (2000) sempre se retroalimentaria do que vem, logo, nunca estaríamos com o Aleph à mão, posto que sempre entregue à torrente do tempo, do outro que vem, sempre um por vir de Aleph, isto também nos emprestaria a noção de volta que queremos aludir agora.

Estamos sempre na ordem. Ela nos instaura e assim fazendo também nos aprisiona, coage. Somos obrigados a dizer. Neste sentido, a obrigação pode ser contornada, podemos ante ela esquivar. Portanto, a literatura, dentro da dimensão de Barthes, seria uma hipótese de manter essa volta, de nos colocamos ante a ordem procurando esses tropos, essa volta, essa astúcia diante de sua coerção.

Mais um passo e convocamos a noção de adio $^{29}$ e que aqui acasala bem com a

\footnotetext{
${ }^{27}$ Encontro sugerida em Barthes uma prática democrática das significações que é desenvolvida por meio de um duplo movimento: Primeiro: a crítica, o combate, a denúncia e a resistência às dimensões simbólicas autoritárias e repressivas; segundo: a prática coletiva, descentralizada e desierarquizada da produção e leitura dos discursos. Detendo-me nas questões concernentes à realização dos discursos democráticos, eu diria que eles se concretizam com a subversão das múltiplas formas com que se apresentam as versões autorizadas do mundo, versões estas com as quais se reprime qualquer relação livre dos discursos com os acontecimentos [...] Apelando a Derrida, apontaria a simbolização democrática como a dinâmica do "descentramento", ou seja, a resistência permanente ao valor semiológico da ideia de unidade e ao vigor totalizador das significações logocêntricas. Insisto na resistência permanente, uma vez que a ocorrência do "descentramento" não é imunizadora em relação ao surgimento de novos processos de recentralização. (WARAT, 1985, p. 69)

${ }^{28}$ A utopia, é claro, não preserva do poder; a utopia da íngua é recuperada como a língua da utopia - que é um gênero como qualquer outro. Pode-se dizer que nenhum dos escritores que partiram de um combate assaz solitário contra o poder da língua, pôde ou pode evitar ser recuperado por ele, quer sob a forma póstuma de uma inscrição na cultura oficial, quer sob a forma presente de uma moda que impõe sua imagem e lhe prescreve a conformidade com aquilo que dele se espera. Não há outra saída para esse autor senão o deslocamento - ou a teimosia - ou os dois ao mesmo tempo. Teimar quer dizer afirmar o Irredutível da literatura: o que, nela, resiste e sobrevive aos discursos tipificados que a cerca: as filosofias, as ciências, as psicologias; agira como se ela fosse incomparável e imortal [...] Teimar quer dizer, em suma, manter ao revés e contra tudo a força de uma deriva e de uma espera. E é precisamente porque ele teima, que a escritura é levada a deslocar-se [...] Deslocar-se pode pois querer dizer: transportar-se para onde não se é esperado. (BARTHES, 1988, p. 12)

${ }^{29} \mathrm{O}$ vadio [vоуи] e o rodado [roué] introduzem a desordem na rua, são designados, denunciados, julgados condenados, apontados com o dedo como delinquentes actuais ou virtuais, como réus, e perseguidos pelo cidadão civilizado, pelo Estado ou pela sociedade civil, pela boa sociedade, pela sua polícia, por
} 
noção que queremos empregar de literatura. Enquanto Barthes nos convoca a trapacearmos com a língua, entendemos que nesse momento resida uma abertura, expliquemos.

Cada vez que a língua é lançada na dimensão da trapaça, necessariamente nos lançamos a refletir acerca daquilo que joga com a língua, que vive no jogo, que também é palavra extremamente relacionada a vadio. Logo, a trapaça apresenta-se aqui também como fuga, porém, não fuga da ordem, mas fuga dentro da ordem. A literatura neste sentido comparece como aquela dá passagem, que cria mais uma passagem, uma via, uma picada na mata ${ }^{30}$.

vezes pelo direito internacional e pelas suas polícias armadas que velam pela lei e pelos costumes (DERRIDA, 2009, p. 134) Porém, a dimensão que o termo ganha para os brasileiros permite-nos um passo a mais em relação à este trazido por Derrida. Trata-se de saber desde logo que desde as Ordenações Filipinas de 1603 já havia uma menção aos vadios: Lei no V, Título LXVIII, "Dos Vadios" Homem que não vive como senhor, ou como amo, nem tiver ofício ou outro mister em que trabalhe, ou ganhe a sua vida, ou não andar negociando algum negócio seu ou alheio, ou dentro de 20 dias, chegado a um lugar, não tiver amo ou ofício, será preso e açoitado". No Código Criminal do Império (1830) havia um capítulo muito alusivo: "Dos mendigos e vadios" que punia a vadiagem: Art. 295. Não tomar qualquer pessoa uma ocupação honesta e útil de que possa subsistir, depois de advertida pelo juiz de paz, não tendo renda suficiente. Penas - de prisão com trabalho por oito a vinte e quatro dias. Porém, a dimensão que mais nos interessa aparece em 1890 no Código Penal da República dos Estados Unidos do Brasil no qual a capoeira - prática restrita aos africanos até então - passa a figurar como crime com um capítulo destinado a ela: Capítulo XIII - "Dos vadios e capoeiras". Art. 402. Fazer nas ruas e praças públicas exercício de agilidade e destreza corporal conhecida pela denominação de capoeiragem: andar em carreiras, com armas e instrumentos capazes de produzir lesão corporal, provocando tumulto ou desordens, ameaçando pessoa certa ou incerta, ou incutindo termos de algum mal. Pena de prisão celular de dois a seis meses. E nosso interesse está ligado a toda a carga estética e histórica que a capoeira carrega, isso permite-nos uma leitura do vadio mais aproximada da realidade brasileira na qual vivemos e que nos interessa sobremaneira dentro de nossa reflexão. "Ouve-se muito falar do termo "vadiação" na capoeira. As canções, cantigas, quadras e corridos sempre estão chamando o jogador para vadiar. Na capoeira, vadiar significa brincar, jogar descontraidamente, usar o espaço da roda para uma espécie de confraternização entre os praticantes. Essa é uma característica comum a diversas manifestações afroculturais presentes no Brasil, como o samba, o jongo, o maracatu, o lundu, coco de roda, etc...A origem dessa característica vem, como já cantava Clara Nunes, "desde o tempo da senzala" [...] Os escravos que fossem pegos sem trabalhar eram chamados e tratados como vadios. Logo, as atividades que não fizessem parte da rotina de trabalho eram entendidas como "vadiação" [...] A vadiação era uma das formas de rebeldia e resistência dos negros, que dessa forma conseguiam burlar a vigilância constante de feitores e jagunços, e em forma de festa, "debaixo do nariz" de seus carrascos, conspiravam a sua revolta. [...] Um texto de Eunice Catunda, contido no livro "O Barracão do mestre Waldemar", do pesquisador Frede Abreu, nos fala justamente dessa urgência que o povo tem de praticar a sua cultura. Para ela a arte, a cultura popular é mais verdadeira, pois não é só uma forma de diversão, e sim uma necessidade imprescindível [...] Vadiar para os escravos era uma forma de festeja, resistir e rebelar, era uma verdadeira arma de guerra. Vadiação é rebeldia, uma rebeldia em forma de festa, uma rebeldia em forma de arte." (CAPOEIRA, 2010) Para além de tudo que vem dito e que alimenta nossa apropriação do termo em nossa escrita, ainda hoje há regulamentação do crime de vadiagem na Lei de Contravenção Penal ainda em vigor no Brasil: Decreto Lei $\mathrm{N}^{\circ} 3.688$ de 3 de outubro de 1941. Capítulo VII Das Contravenções relativas à Policia dos Costumes. Art. 59. Entregarse habitualmente à ociosidade, sendo válida para o trabalho, sem ter renda que lhe assegure meios bastante de subsistência, ou prover à prova subsistência mediante ocupação ilícita: Pena - prisão simples, de quinze dias a três meses. Portanto, sempre que usarmos esse termo, estaremos necessariamente a levar em consideração toda a dimensão que aqui foi explicitada. (BRASIL, 1941)

${ }^{30}$ É de extremo relevo dizer que Derrida desenvolve o termo vadio em uma dimensão da relação entre 
Já estamos assentes quanto à noção de ordem, percebemos também que aquilo que vem como ordem coage, e mais, a ordem impõe-se, estar nela é estar coagido por ela. Coagido a agir conforme ela, nesse momento da reflexão, coagido a falar. Entretanto com essa hipótese que aparece, com essa volta, nessa volta mesmo encontramos com os vadios. O vadio seria sempre aquele que se põe pela ordem para fora da ordem, aquele que via-de-regra se põe fora-da-lei. E o termo via-de-regra não é em vão chamado aqui. O termo via, como nos ensina Jacques Derrida, tem uma relação aproximada com a palavra vadio ${ }^{31}$. Ele corrompe a rua com sua dimensão de vadio, altera a ordem da via, a regra da via. Por isso, a via ao mesmo tempo é o local que habita o vadio assim como é aquilo a que ele confere um outro uso, aquilo que ele profana. Logo, a via é em regra, é a regra que se segue, pela qual seguimos, mas que o vadio por vezes também faz de morada, e por isso mesmo, dá a ela outra dimensão, confere um uso distinto daquele sacralizado (acompanhando Giorgio Agamben) imposto por exemplo pelas placas que determinam qual a via a seguir. Os vadios não respeitam as placas, via-de-regra eles assaltam as placas. A via é a casa do vadio, ele a habita, ele faz dela outra coisa, diferente daquilo para a qual ela fora "criada".

Em poucas palavras, o vadio é aquele que vagueia, aquele que não dá à ordem a importância que ela quer ter, o vadio incomoda a ordem, ele turba, ele é a turba. E aqui importa mais uma vez relembrar como a noção de via, de regra, de soberania das regras - regra na mesma dimensão de lei - impõe um modus vivendi, isso esperamos ter ficado claro quando falamos do soberano e agora pela figura do vadio, que desde o nascimento da ordem será por ela perseguido.

Assim, o vadio é uma figura que está sempre na via. $\mathrm{Na}$ via ele inventa/trapaceia os seus modos de estar. Mas ele é uma figura que está ali sempre a ponto de ser levado diante da lei. Ele tem sempre sobre si um dedo apontado. A ordem

\footnotetext{
Estados para ao fim mostrar que aquele que aponta e nomina um outro estado como estado vadio, o faz em uma dimensão de soberania, portanto, como já mostramos na análise, em um exercício de violência e apropriação típica dos lobos, por isso, ao fim mostra-nos Derrida que se há estados vadios, só podem existir estados - todos eles - vadios, pois a acusação sempre se dá na medida de quem adjetiva, cataloga o outro a partir de sua soberania como vadio pela força e pelo interesse e pelo abuso do poder e pelo abuso da lei. Nesse momento de nosso trabalho a alocução vadio funciona para mostrar a hipótese que levantamos de enxergar na vadiagem/trapaça da literatura uma saída ante o fascismo da língua. Para tanto ver (DERRIDA, 2009, p. 155ss)

31 A palavra voyou [vadio] tem uma relação essencial com a voie [via], com a lixeira urbana, com a manutenção da cidade ou da polis, e portanto com a rua, consistindo o desvio do [dévioement] do vadio num mau uso da rua, em corromper a rua, em vaguear pelas ruas, "bater as ruas" ["courir les rues"], como se diz de maneira estranhamento transitiva. Uma tal transitividade não está nunca longe daquela que permite "andar na vida" ["faire le trottoir]. (DERRIDA, 2009, p. 136)
} 
persegue o vadio. E nas formas mais usuais da língua encontra-se a referência ao vadio sempre de maneira negativa, sempre como um escárnio ou até mesmo uma condenação. O vadio é sempre aquele contra o qual a ordem está pronta para se proteger. Ele enquanto turba, turba de vadios, ameaça a ordem.

A partir dessa aproximação do vadio com a trapaça de Barthes encontramos uma oportunidade para operarmos dois movimentos. Um, mostrar como a literatura em algum sentido dito por Barthes se assemelharia a esses vadios em sua posição ante a ordem. Outro, mostrar como essa volta, que é uma andança em círculo, entretece no círculo e daí pode inventar o que não estava à vista. De algum modo, a questão da invenção, de uma leitura que faremos da desconstrução como uma hipótese de invenção restará aqui anunciada.

O verbo trapacear trazido por Barthes a nos anunciar a escapada que a literatura permite trabalhar muito aproximado daquilo que denota o vadio, pois a trapaça é aquilo que se realiza sem que se respeite as regras do jogo, e isso carrega uma semelhança imensa com a noção de vadio, que sempre é apontado como aquele que não respeita as regras do jogo; do jogo, leia-se, da ordem, do soberano.

A literatura seria a chance da trapaça, portanto, a literatura seria a hipótese do vadio. No estar do vadio, na sua própria forma de se dar ao mundo, ante o mundo e ante a ordem, residiria o tropos que nos ensina Barthes. A literatura "permite ouvir a língua fora do poder, no esplendor de uma revolução permanente" (BARTHES, 1988, p. 15). O vadio seria em nossa leitura a própria língua fora do poder. Não há que se pensar em algo fora da polis, o vadio sempre está cercado pela polis, ele sempre o é na dimensão dessa ordem soberana, por isso é tão importante a reflexão que nos empresta a literatura. Ela permite a trapaça que a mais das vezes é a própria dicção de um idioma outro, de um idioma que vem do outro, de um idioma vadio, que alojado no interior da ordem, criado por ela, age dentro dela para transformá-la ${ }^{32}$.

\footnotetext{
${ }^{32} \mathrm{~A}$ noção de infiltração pode ser um bom aliado para abrirmos os flancos que estamos a trabalhar: "A ideia de infiltração (infiltrações) pode ser, neste sentido, potencialmente transformadora. No que consiste? Em práticas diárias, múltiplas, individuais, coletivas, locais, regionais, pessoas, organizações, coletividades, comunidades, cidades, regiões, etnias, coletivos de trabalhadores, sem-teto, sem-terra, artistas, enfim pessoas coletivas ou singularidades coletivas diversas que fazem diferente, que não reproduzem o sistema moderno em sua essência, especialmente, que desconsideram as práticas hegemônicas e padronizadoras modernas. As infiltrações não seriam práticas contra o sistema, mas, práticas além do sistema, que negam as práticas excludentes. A ideia de novos usos de Giorgio Agambem pode ser muito importante para a compreensão destas práticas. Agambem se refere aos mitos, ritos e sacralizações, e constrói uma ideia importante para desenvolvermos a ideia de infiltração: profanações." (MAGALHÃES, 2016, p. 2)
} 
Ante o fascismo que a língua impõe, opomos esse tropos vadio, a trapaça que Roland Barthes (1988) ensina. Trapacear com a ordem não é negá-la, apesar de ser também possível, mas é abrir uma hipótese de hospitalidade também, é abrir um espaço, um meio, um respiro, para que a invenção possa aparecer. Essa luta se dá no terreno, logo, aos atos de encontro do direito com a literatura talvez seja importante associar a dimensão da hospitalidade e da invenção.

Logo, pensamos que é sempre importante levar em consideração aquilo que não está dado pela ordem. O vadio tem uma relação dúbia com a ordem, ele a perturba, porém, é ele também que empresta condição para a ordem se impor a ele como tal vadia? E é importante, é preciso que exista essa perturbação, sob pena de estarmos entregues e passivos aos desígnios da própria língua ${ }^{33}$. A literatura não seria a panaceia $^{34}$ na qual tudo se daria de maneira feliz, tampouco ela se daria como o cordeiro. Não é disso que se trata, tampouco, de nos valermos dela como utensílio, como ferramenta, não. Na relação com o direito que estamos a propor, a literatura comparece como o local em que a trapaça vem, o vadio comparece, e para lembrarmos a figura do círculo que aludimos acima, a cada volta de um no outro, do outro pelo um, o círculo, como o Aleph, pode sempre se tornar um outro círculo.

A dimensão da trapaça está colocada junto da invenção dentro de nossa reflexão. E essa afirmação também vem carregada de uma necessidade de explicação, e ela é simples: a invenção que segue todos os padrões, a invenção programada, programável, pode-se dizer, não seria, de fato, invenção. É sempre necessário trapacear para inventar. E essa trapaça vadia ${ }^{35}$ seria a própria dimensão que a literatura assumiria

\footnotetext{
${ }^{33}$ A literatura é de oposição: ela tem o poder de contestar a submissão ao poder. (COMPAGNON, 2009, p. 34)

${ }^{34}$ As definições clássica e romântica do poder da literatura não são mais correntes - instruir deleitando, atenuar a fragmentação da experiência -, mas um projeto moderno ou mesmo modernista fazendo da literatura uma filosofia, até mesmo a filosofia, isto é, a ultrapassagem dos limites da linguagem ordinária. (COMPAGNON, 2009, p. 37)

${ }^{35}$ Para além das discussões trazidas neste tópico, gostaríamos de aludir que a dimensão que a literatura acaba por assumir aqui poderia compor uma série de discussões sobre o que deveria ser considerado literatura, para além do conceito de Barthes já discutido, importa mencionar que ali onde fala-se literatura não impõe-se um edifício de autores e obras, ao contrário, dentro de uma dimensão que também nos empresta a "ecologia dos saberes" de Boaventura de Sousa Santos, essa "hierarquia" e essa catalogação não interessam ao nosso intento que, ademais, estará sempre na estrada de uma dimensão horizontal e democrática: "Portanto, a luta pelos direitos humanos abrange a luta por um estado de coisas em que todos possa ter acesso aos diferentes níveis da cultura. A distinção entre cultura popular e cultura erudita não deve servir para justificar e manter uma separação iníqua, como se do ponto de vista cultural a sociedade fosse dividida em esferas incomunicáveis, dando lugar a dois tipos incomunicáveis de fruidores. Uma sociedade justa pressupõe o respeito dos direitos humanos, e a fruição da arte e da literatura em todas as modalidades e em todos os níveis [...]" (CANDIDO, 2011,
} 
aqui em nossa discussão. Um momento no qual é possível, não necessário, tampouco, garantido, que as coisas se deem, se doem, de maneira diferente, restaria talvez inventá$10^{36}$

A literatura traz uma face subversiva para dentro da ordem, porém, ela nunca se confundirá com a ordem, há sempre uma tensão entre o instituído e aquilo que vem enquanto literatura ${ }^{37}$, sem amarras, sem regras; esse encontro, tal como no encontro do direito com a justiça, nos oportuniza dizer mais uma vez que estaremos nesta ordem de considerações, do direito à literatura, não como confusão de um com o outro, tampouco, como forma de tornar o direito literatura, isso não nos parece adequado; mas sim tomando como proveito que estas duas dimensões se constituem na ordem da linguagem ${ }^{38}$, fazer com que sempre exista esse assombro, esse reclame, esse questionamento, essa procura, para terminarmos como iniciamos, de um entretecimento de uma no outro, para um alargamento da ordem, para sua desconstrução, se quisermos.

Outra vez, nunca haverá confusão, tampouco, poderíamos olvidar ao infinito que é a literatura ${ }^{39}$. O impossível é a literatura enquanto aquilo que resta por ser inventado, o humano aspira a essa dimensão. No encontro com o outro há a hipótese do início ou do fim, preferimos aqui não virar as costas ao que vem sob o argumento de não se encaixar na ordem, em verdade, ele já está aí: a literatura pode nos ajudar a deixá-lo vir. Estaremos sempre à, nunca no fim desta discussão.

Quando falamos do direito à literatura talvez possamos dar a pensar que a questão gira em torno de um direito à literatura. Essa temática já fora abordada por

p. 193)

${ }^{36}$ Para a constituição de uma prática democrática é necessário, a meu ver, que o poder, a lei e o saber fiquem expostos simbolicamente à sociedade para a reconstituição permanente do social e para o controle participativo do poder do Estado. Neste ponto eu estou com Lefort. A democracia precisa ser sentida como uma invenção constante do novo. Ela se reconhece no inesperado que resiste aos equilíbrios demasiadamente sólidos de uma ordem de proibições. Obviamente o novo de que falo não é uma fuga de estereótipos à procura de uma readaptação autoritária dos discursos. Não é o novo pelo novo. (WARAT, 1985, p. 70)

${ }^{37}$ Mutatis mutandis: Perceber, portanto, que a conexão entre o sistema social artístico, onde se encontra a Literatura, e o sistema social do Direito, é um espaço de mútua irritação capaz de produzir novas respostas e novas operações para cada um dos referidos sistemas é a contribuição principal da teoria autopoiética para a co-relação Direito/Literatura. (SCHWARTZ, 2006, p. 39)

38 Precisamente porque o mundo do Direito é um mundo que se move, nas suas mais diversificadas facetas, ao longo dos trilhos sulcados pela palavra, pelo texto, pelo discurso escrito ou oral. Seja a letra dos códigos ou a sentença do magistrado, trate-se do argumento do causídico ou da palestra do académico, a normatividade jurídica tem uma existência eminentemente verba e textual. (SILVA, 2011, p. 33)

${ }^{39} \mathrm{O}$ poeta dispõe do poder não mais arcaico, mas moderno [...] de desvelar uma verdade que não seja transcendente mas latente, potencialmente presente, escondida fora da consciência, imanente, singular e, até aí, inexprimível. Brincando com a língua, a poesia ultrapassa suas submissões, visita suas margens, atualiza suas nuanças e enriquece-a violentando-a. (COMPAGNON, 2009, p. 38) 
Antônio Cândido em texto já mencionado, porém, como parece termos deixado claro, importa percebermos que estamos a perscrutar um movimento, aquele que ao trazer a dimensão da ordem para junto da literatura pode vislumbrar uma dimensão que restaria ocultada. A dimensão vadia da literatura opera como trânsito constante que permite que a via seja acessada de maneira distinta daquela que a ordem determina. Cada vez que houver esse encontro, a ordem, em nossa percepção, é colocada sob suspeita. A partir da literatura podemos fazer a ordem girar, sempre na dimensão que trouxemos, do jogo, da capoeira, do vadio que é a própria literatura nestas ordens de considerações.

\section{REFERÊNCIAS}

BARTHES, Roland. Aula: aula inaugural da cadeira de Semiologia Literária do Colégio de França pronunciada dia 7 de janeiro de 1977. Tradução de Leyla Perrone-Moisés. São Paulo: Cultrix, 1988.

BORGES, Jorge Luís. “O alef”. In: Obras Completas III. Paulo: Globo, 2000.

BORRADORI, Giovanna. Filosofia em tempo de terror. Tradução de Jorge Pinho. Porto: Campo das Letras- Editores S.A., 2004.

BRASIL. Decreto Lei no 3.688 de 3 de outubro de 1941. Lei das contravenções penais. Brasília, DF: Presidência da República, 2018. Disponível em: <http://legis.senado.leg.br/sicon/index.html;jsessionid=A13C0903997AC03334449265 71349997\#/pesquisa/lista/documentos>. Acesso em: 26 jan. 2010.

CANDIDO, Antônio. "O direito à literatura". In: . Vários escritos. 5 ed. Rio de Janeiro: Ouro Sobre Azul, 2011. p. 171-193.

CAPOEIRA, Soldado. A arte da vadiação. [S. 1.]: Horadacapoeira, 2010. Disponível em: < http://ahoradacapoeira.blogspot.com.br/>. Acesso em: 28 maio 2019.

CAPUTO, Jonh. "Após Jacques Derrida vem o futuro". Tradução de José Carlos Felix. Revista de Letras, São Paulo, v. 49, n.2. p. 173-179, jul./dez. 2009.

"Por amor às coisas mesmas: o hiper-realismo de Derrida". In: DUQUEESTRADA, Paulo Cesar (Org.). Às margens: a propósito de Derrida. Rio de Janeiro: Ed. PUC-Rio; São Paulo: Loyola, 2002. p. 29-48.

COMPAGNON, Antoine. Literatura para quê? Tradução de Laura Taddei Brandini. Belo Horizonte: Editora UFMG, 2009.

CRUZ, Álvaro Ricardo de Souza. "Prefácio". In: ZHOURI, Priscila Rainato. Jurisdição diferAnte: o embate entre violência e justiça na democracia. Belo Horizonte: Arraes Editores, 2017. Disponível em: 
<http://www.arraeseditores.com.br/media/ksv_uploadfiles/o/l/olho__jurisdi_o_diferante.pdf >. Acesso em: 19 out. 2017.

DERRIDA, Jacques. Anne Dufourmantelle convida Jacques Derrida a falar da hospitalidade. Tradução de Antonio Romane e revisão técnica de Paulo Ottoni. São Paulo: Escuta, 2003.

. A besta e o soberano: Seminário 2001-2002. Edição estabelecida por Michel Lisse e Marie-Louise Mallet et Ginette Michaud. Rio de Janeiro: Via Verita, 2016.

Essa estranha instituição chamada literatura: uma entrevista com Jacques Derrida. Tradução de Marileide Dias Esqueda, revisão técnica e introdução de Evando Nascimento. Belo Horizonte: Editora UFMG, 2014.

Força de lei: o fundamento místico da autoridade. 2. ed. Tradução de Leyla Perrone-Moisés. São Paulo: WMF Martins Fontes, 2010.

Vadios dois ensaios sobre a razão. Coordenação científica da edição, tradução e notas Fernanda Bernardo. Tradução de Fernanda Bernardo, Hugo Amaral, Gonçalo Zagalo. Revisão da tradução Fernanda Bernardo, Hugo Amaral. Coimbra: Terra Ocreunip. Ltda, 2009.

; SPIRE, Antoine. Para além das aparências. Alcochete: Textiverso Lda., 2008.

GRENHA, Tatiana. Herança e escritura em cena: um estudo sobre Freud em Derrida. 2004. 103f. Dissertação (mestrado) - Pontifícia Universidade. Rio de Janeiro: PUC-Rio, Departamento de Filosofia, 2004.

LA FONTAINE, Jean de. Fábulas. Trad. por Ferreira Gullar. Rio de Janeiro: Revan, 1997.

MAGALHÃES, José Luiz Quadros de. Direito à diversidade e infiltrações transformadoras. [S. 1.]: FAA, 2016. Disponível em:

<http://faa.edu.br/revistas/docs/RID/2016/FDV_2016_04.pdf>. Acesso em: 29 maio 2017.

Ética, cotidiano e corrupção. Belo Horizonte: 2012. [Palestra realizada na PUC-Minas, no curso de Filosofia, no segundo semestre de 2012.] Disponível em: <http://joseluizquadrosdemagalhaes.blogspot.pt/2012/12/1275-etica-cotidiano-ecorrupcao-coluna.html>. Acesso em: 29 maio 2017.

NASCIMENTO, Evando. "Introdução”. In: DERRIDA, Jacques. Essa estranha instituição chamada literatura: uma entrevista com Jacques Derrida. Tradução de Marileide Dias Esqueda, revisão técnica e introdução de Evando Nascimento. Belo Horizonte: Editora UFMG, 2014.

ROSA, João Guimarães. Grande sertão: veredas. Rio de Janeiro: Nova Aguilar, 1994b. 2v. v.2. (Série Brasileira, João Guimarães Rosa Ficção). 
completa, 2).

A terceira margem do rio. Rio de Janeiro: Nova Aguilar, 1994a. (Ficção

SANTOS, Boaventura de Sousa. Aulas magistrais: A Sociologia Pós-Abissal:

Metodologias Não Extractivistas [S. 1.]: Youtube, 17 maio 2017. [Participation of Renan Inquérito]. Disponível em: < https://www.youtube.com/watch?v=1SHnc6P7Z6A >. Acesso em: 03 set. 2017.

SCHWARTZ, Germano. A Constituição, a literatura e o direito. Porto Alegre, RS: Livraria do Advogado Ltda, 2006.

SILVA, Joana Aguiar e. Para uma teoria hermenêutica da Justiça: repercussões jusliterárias no eixo problemático das fontes e da interpretação jurídicas. Coimbra: Edições Almedina SA, 2011.

SILVA, Luis Renato Ferreira da. "O tempo no direito e o tempo do direito: provocação para uma releitura entre direito e literatura a partir de um tema borgiano". In:

MARTINS-COSTA, Judith. Narração e normatividade: ensaios de direito e literatura. Rio de Janeiro: GZ Ed., 2013. p. 95-100.

STRECK, Lenio Luiz; TRINDADE, Andre Karan. Direito e literatura: da realidade da ficção à ficção da realidade. São Paulo: Atlas, 2013.

WARAT, Luís Alberto. A ciência jurídica e seus dois maridos. Santa Cruz do Sul: Faculdades Integradas de Santa Cruz do Sul, 1985.

WOLFREYS, Julian. Compreender Derrida. Tradução de Caesar Souza. Petrópolis: Vozes, 2009.

ZIZEK, Slavoj. Violência: seis reflexões laterais. São Paulo: Boitempo, 2014.

\section{Recebido em: 01/11/2021}

Aprovado em: 30/11/2021

Publicado em: 03/12/2021 